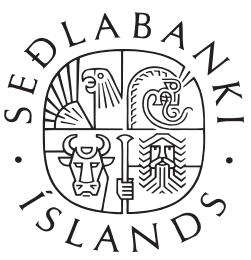

CENTRAL BANK OF ICELAND

WORKING PAPERS No. 1

\title{
INFLATION AND DISINFLATION IN ICELAND
}

$$
\text { by }
$$

Palle S. Andersen and Már Guðmundsson

January 1998

CENTRAL BANK OF ICELAND

Economics Department 
Central Bank of Iceland Working Papers are published by the Economics Department of the Central Bank of Iceland. The views expressed in them are those of their authors and not necessarily the views of the Central Bank of Iceland.

Also available on the Central Bank of Iceland World Wide Web site (http://www.sedlabanki.is)

All rights reserved. May be reproduced or translated provided the source is stated.

ISSN: 1028-9445 


\title{
INFLATION AND DISINFLATION IN ICELAND
}

\author{
by
}

Palle S. Andersen and Már Guðmundsson*

January 1998

\begin{abstract}
Iceland was a high inflation country from the second half of the seventies and until the middle of the eighties. During the middle of the nineties inflation in Iceland, at less than $2 \%$ p.a., was among the lowest in the OECD. In this paper we analyse the roots of high inflation in Iceland and the subsequent disinflation episode. We find that high inflation in Iceland was caused by an increased frequency of external shocks, a tight labour market and a stronger devaluation bias. We further find that disinflation took place in two stages. The first was initiated in 1983 by a policy package of statutory incomes policy and a firmer commitment to exchange rate stability as a response to an inflation crisis. It reduced inflation from the high to the moderate range at negligible cost in terms of output and employment. The second stage took place during the early nineties and reduced annual inflation from the moderate range to below 3\%. It involved more fundamental changes in policy priorities and public attitudes than the first stage and is more unique in the international context. It was also more costly in terms of output and employment than the first stage, although the costs seem to have been rather small compared to some other countries. A relatively high degree of real wage flexibility, the use of incomes policy, widespread financial indexation and, above all, a broadly based consensus that the general public was best served by low inflation all contributed to this outcome.
\end{abstract}

JEL: E31-E44-E52-E65

\footnotetext{
* Bank for International Settlements and Central Bank of Iceland. The views expressed in this paper are those of the authors and do not necessarily have to reflect the views and policies of our institutions. We are indebted to Phillip Hainaut, Gerður Ísberg, Stefán Sigurðsson and Thórarinn G. Pétursson for research assistance. We would also like to thank without implication participants at seminars in the Central Bank of Iceland and at the BIS for useful comments.
} 


\section{Contents}

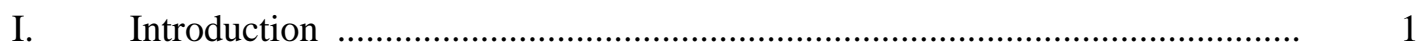

II. A summary of the history of post-war inflation in Iceland ............................ 2

III. The roots of inflation in Iceland …................................................................

IV. The process of disinflation ……................................................................. 8

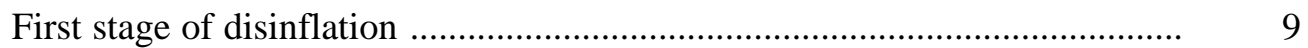

Post-stabilisation period ....................................................................... 11

Second stage of disinflation ................................................................... 13

V. Costs of inflation and disinflation ................................................................. 17

VI. Iceland's comparative performance ………................................................ 22

VII. Specific features of the disinflation process in Iceland ................................. 29

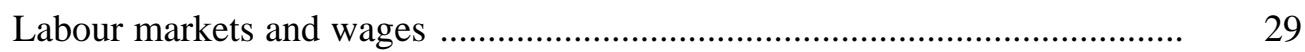

Financial indexation ........................................................................... 35

The role of fiscal and monetary policies ...................................................... 39

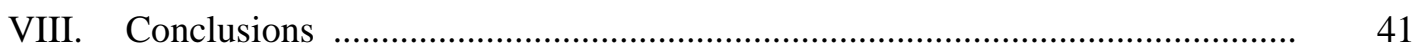

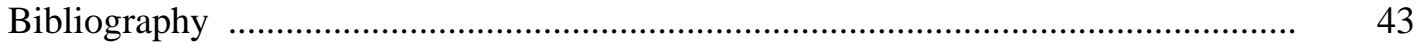

Annex A: A model of inflation in Iceland ............................................................... 46

Annex B ……............................................................................................ 50

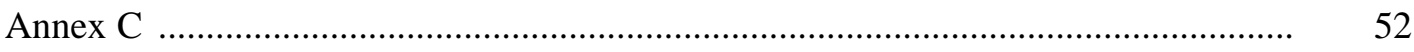

Annex D: Inflation expectations ………………………………………………... 53 


\section{Introduction}

"Iceland's inflation history is unique among the OECD Member countries. Following the first two post-war decades, with annual price increases hovering between 10 to $15 \%$, the $1970 \mathrm{~s}$ saw a radical worsening of inflation, far beyond what was observed elsewhere. Indeed the average rate of inflation in each cycle ratcheted upwards, from around 14\% in the early 1970s to more than 60\% in the beginning of the 1980s. Moreover, the duration of each cycle shortened, as did the period in which it proved possible to maintain the benefits of anti-inflation policies." OECD Economic Survey of Iceland, 1983, p.9.

"For a second year in a row Iceland's economy performed beyond expectations. In 1994 real GDP registered moderate growth...; the unemployment rate stabilised...; the current account was in sizeable surplus....; and consumer price inflation was 1.5\%, well below official projections."

OECD Economic Survey of Iceland, 1995, p. 1.

These two quotes clearly illustrate an achievement that is fairly unique in the history of inflation and disinflation: from a peak of nearly $85 \%$ in 1983 Iceland managed, in the course of just eleven years, to reduce the rate of inflation to only $1.5 \%$. Moreover, disinflation was not only very rapid but also achieved with surprisingly small output and employment costs. In fact, the sacrifice ratio, measured in terms of unemployment, is only 0.12 for the whole period of disinflation, ${ }^{1}$ and probably lower than for any other OECD country. ${ }^{2}$

However, as discussed later in this paper, looking at the 1983-94 period as a whole gives a misleading impression of the nature of the disinflation process. In fact, there were two phases of disinflation and they differ significantly with respect to the degree of disinflation, the associated costs and, not least, the policy measures taken. The first phase started in 1983 and while it produced an impressively large fall in inflation at relatively low costs, the policy changes did not go deeply enough. In particular, they hardly changed the sensitivity to external shocks nor the bias towards policies which channelled external shocks into higher domestic inflation; i.e. the propagation mechanism which was the root cause of the acceleration in the early 1980s.

The second phase, starting in 1990, went much deeper and involved major changes in policies and policy priorities. It was also more costly in terms of higher unemployment, despite a high degree of real wage flexibility, financial indexation and a growing perception among the general public and the trade unions that Iceland was best served by low and stable inflation. However, since the benefits of low inflation arrive with a long lag, it is probably still too early to assess the ultimate net costs of this second phase.

On the following pages we attempt to analyse in greater detail Iceland's experience with

1. The sacrifice ratio is calculated as the cumulative rise in the rate of unemployment between 1983 and 1994, divided by the decline (in absolute terms) in the rate of inflation over the same period.

2. For instance, the sacrifice ratio for the EU countries between 1981, when inflation peaked at over 13\%, and 1996, when inflation averaged only $2 \frac{1}{2} \%$, is about 3.7 . 
inflation and disinflation. Section II summarises the history of postwar inflation, followed, in section III, by a discussion of the role of external shocks and the mechanism by which such shocks were channelled into domestic inflation. Section IV analyses the two phases of the disinflation process and section $\mathrm{V}$ provides a general assessment of the costs of inflation and disinflation. In section VI we take a broader perspective by comparing Iceland's experience with disinflation with those of other countries while section VII looks at specific features of Iceland's disinflation process, notably the role of labour market flexibility, financial indexation and the contribution of fiscal and monetary policies. In section VIII we summarise the major findings. There are four annexes to the paper. Annex A estimates a model of inflation which is used several times in the main text. Annex B summarises major macroeconomic developments during the two phases of disinflation while Annex $\mathrm{C}$ provides a list of countries which have experienced three years with inflation rates of $30 \%$ and of where they are today. Finally, Annex D presents various simple models of the inflation expectations mechanism.

\section{A summary of the history of post-war inflation in Iceland}

Throughout the post-war period, inflation in Iceland has been substantially higher than the OECD average (Graph 1). Moreover, the rate of inflation was not stable ${ }^{3}$ but progressively accelerated between the 1960s and the 1970s, reaching over $80 \%$ during the early $1980 \mathrm{~s}$. At the same time, Iceland's growth performance was relatively favourable, as GDP growth averaged $4.5 \%$ in the $1960 \mathrm{~s}$, as much as $6.3 \%$ in the 1970 s but then only $2.7 \%$ in the 1980 s. However, due to Iceland's exposure to external shocks, growth was not very stable either and, at over $5 \%$, the year-to-year variability of output growth has been well above that of most other countries.

Following the classification of Dornbusch and Fisher (1991), ${ }^{4}$ Iceland's inflation was low from 1945 until 1973 as it averaged just above 91/2\% per annum and never went above $15 \%$ for more than two years in a row (Graph 1). In 1974 inflation moved into the high range where it stayed until 1984, averaging 49\%. According to the terminology in Easterly (1996), there were two inflation crises during the high inflation period. The first, caused by the domestic response to the international oil crisis, occurred during 1974-75 and was followed by stabilisation in 19771978. The second, due to negative supply shocks reinforced by a strong devaluation bias, took place in 1978-1983 and at the end of that crisis, inflation was threatening to become extreme.

3. As is typical of countries with a high average rate of inflation, the year-to-year variability has also been quite high. The standard deviation for the period 1960-95 was 19.2\%, compared with an average inflation rate of $22.5 \%$; for the 1963-92 period, Judson and Orphanides (1996) report a standard deviation for Iceland which is about twice the average rate.

4. Numerical definitions of inflation are far from being standardised and, to clarify the concept used and avoid including short-term supply shock episodes, it is necessary to complement the numerical definitions with a specific timeframe. In the following, we shall mainly follow the suggestions by Dornbusch and Fischer and refer to inflation as moderate when annual price increases are in the 15-30\% range over periods of at least 3 years, as low for annual price increases under 15\%, as high for annual price increases in the 30-100\% range, as extreme for annual price increases in the 100-1000\% range and as having reached a state of hyperinflation when price increases exceed $1000 \%$. 


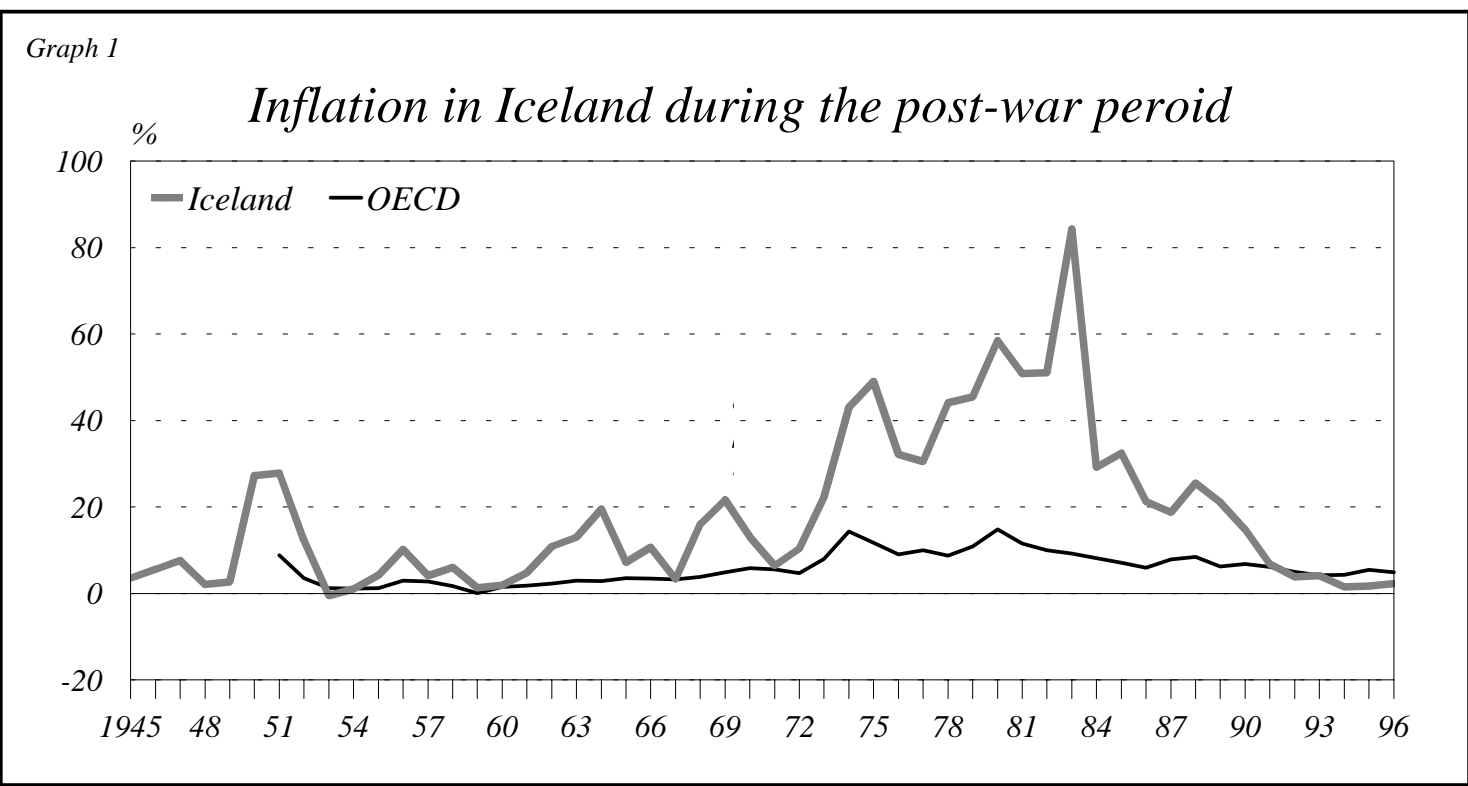

The stabilisation that followed in 1983-1984 reduced inflation in Iceland to the moderate range. 5 It stayed in this range until the second phase of disinflation brought it into the low range in 1990 and subsequently to the vicinity of the operational definition of price stability from 1994 onwards. 6

Using the methodology of Ball (1993) and Debelle (1996), four disinflation periods in Iceland can be identified for quarterly data since the early 1960s (Table 1). The first two came in the wake of negative supply shocks that prompted devaluations but did not involve significant disinflation programs. As these shocks went away and the exchange rate stabilised, the rate of inflation came down again. In contrast, the following two periods involved a wide range of disinflationary measures. Taken together they were also of historical proportions as they brought inflation in Iceland all the way from the high range to $1-3 \%$ which is the level aimed at by many central banks that use inflation targeting. These disinflations will be the main topic of this paper. However, first we turn our attention to the sources of inflation in Iceland and the reasons for the high inflation during 1974-1983.

Table 1. Disinflation periods in Iceland 1962-1996

\begin{tabular}{|l|r|r|r|r|}
\hline Period in quarters & $\begin{array}{r}\text { Length of } \\
\text { period }\end{array}$ & $\begin{array}{r}\text { Initial } \\
\text { inflation }\end{array}$ & $\begin{array}{r}\text { Fall in } \\
\text { inflation }\end{array}$ & $\begin{array}{r}\text { Inflation at end } \\
\text { of period }\end{array}$ \\
\hline $1969: 4-1971: 2$ & 6 & 16.7 & 6.1 & 10.6 \\
$1975: 1-1977: 1$ & 8 & 44.9 & 14.3 & 30.6 \\
$1983: 1-1987: 2$ & 17 & 64.5 & 43.7 & 20.8 \\
$1989: 1-1995: 2$ & 25 & 24.2 & 22.6 & 1.6 \\
\hline
\end{tabular}

5. During the period of moderate inflation from 1984 to 1989 inflation averaged nearly $25 \%$.

6. Here we are referring to an inflation rate in the 1-3\% range; see also Fischer (1996). 


\section{The roots of inflation in Iceland}

The literature identifies three motives which, historically, have led governments to inflate or depreciate their currencies: the employment motive, the revenue motive and the balance of payments motive. ${ }^{7}$ While the same three motives also help to explain why governments are often reluctant to reduce inflation, an additional reason for leaving the rate of inflation high is that inflexible wages and/or a high degree of wage indexation may further raise the costs of lowering inflation. To what extent do these motives and factors explain the history of post-war inflation in Iceland and why were serious attempts to bring inflation into line with that of most other countries not undertaken until the late 1980s?

The seigniorage motive is probably most important in countries with underdeveloped tax systems, although the high rate of inflation in Iceland during the seventies and the first half of eighties might indicate that it was also rather important in Iceland during this period. However, estimates of seigniorage that are based on the opportunity cost approach, and thus take account of the Central Bank's interest payments on banks' reserve requirements suggest that seigniorage amounted to only $3 \%$ of GDP when it peaked in 1974 and fell to $2-2 \frac{1}{2} \%$ in 1983 even though inflation was then higher. ${ }^{8}$ The reason was that interest payments on reserve requirements were much more generous during the eighties than during the seventies and that currency in circulation was smaller in relation to GDP. ${ }^{9}$ Indeed, the revenue motive has not been of any great importance to the Icelandic inflation process and has never played any significant role in the economic policy discussion. Consequently, we generally agree with Dornbusch and Fischer that in countries, such as Iceland, where alternative sources of revenues are readily available, seigniorage has rarely been considered an argument for inflation or for keeping inflation high. ${ }^{10}$

As regards the employment and the balance of payments motives, their influence needs to be seen in the context of Iceland's proneness to external shocks. In fact, the main sources of inflation in Iceland during the $70 \mathrm{~s}$ and 80 s have been a combination of the following five factors: adverse external shocks; policy responses to these shocks with a significant devaluation bias; a generally accommodating monetary stance; a very tight labour market reflecting the fullemployment policy of the authorities; and various institutional arrangements that eased the perceived costs of high inflation.

Graphs 2 and 3, together with Table 2 and the two-equation model of inflation presented in Annex A, illustrate these arguments. In Graph 2, external shocks have been proxied by the annual percentage change in the purchasing power of exports (or "real" export revenue), measured as

7. See, for example, Cukierman (1992).

8. See Hansson (1997).

9. Price indexation plus a $2 \%$ interest rate was paid on required reserves on indexed deposits in the banking system from the middle of 1980 and interest rates on other required reserves followed bank rates. In 1987 all required reserves were price indexed but did not bear any interest rate on top of that until 1988 onwards. Notes and coins in circulation were above $2 \%$ of GDP in the first half of the seventies but had become less than $1 \%$ of GDP during the early eighties.

10. See, however, IMF (1996) which gives more weight to the seigniorage argument. 


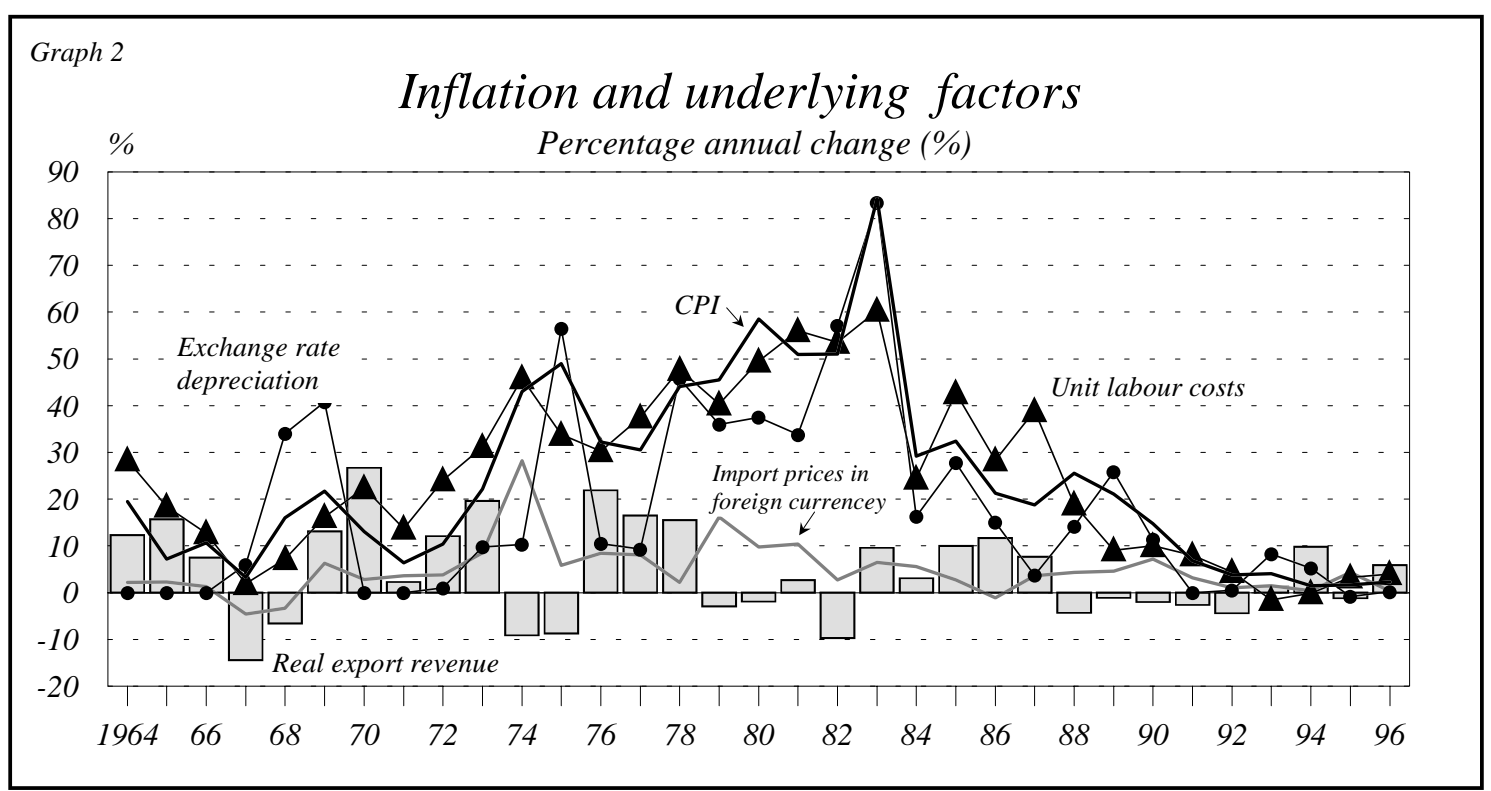

export revenue deflated by import prices. ${ }^{11}$ As the graph shows, inflation (measured by either consumer prices or unit labour costs) usually peaks one or two years after the economy is hit by negative external shocks (defined as a decline in real export revenue) and these peaks are always associated with a devaluation. ${ }^{12}$ Graph 3 illustrates labour market developments in Iceland by developments in the rate of unemployment from 1964 and the vacancy rate from 1985. ${ }^{13}$ As the graph shows, unemployment was well under 1\% during the 1970s and even though it increased somewhat during the mid-1980s, it stayed below $1 \frac{1}{2} \%$ until 1989. At the same time, the vacancy rate exceeded the unemployment rate until 1989 when it actually became negative, indicating that employers wanted to shed labour. The labour market was thus in a chronic state of excess demand until 1989 but, as will be discussed later, this balance changed dramatically during the 1990s.

11. As defined, external shocks are measured as the product of the quantity of exports and the terms of trade. The terms of trade can be assumed to be mostly given for an economy as small as that of Iceland and the quantity of exports is also to a great extent determined by exogenous factors, such as the fish catch and foreign demand. The purchasing power of export revenue is thus a reasonably good measure of external shocks and has actually been the driving force of the Icelandic economy over the medium run. Nearly $90 \%$ of the variance in national income over the period 19601994 can be explained by current and lagged changes in the terms of trade. Moreover, national income in constant prices can be explained by an error correction model, with exports in constant prices and the terms of trade as explanatory variables. The data are annual and spans from 1960 to 1996. The model is of the error correction form (with heteroscedastic consistent $t$-values in parenthesis):

$$
\Delta y_{t}=\underset{(7.52)}{0.431+}+0.322 \Delta x_{t}+0.628 \Delta \lambda_{t}-0.480\left(y_{t-1}-x_{t-1}\right)-0.487\left(y_{t-1}-\lambda_{t-1}\right)+0.395 y_{t-1}
$$

OLS, $1960-1996, \bar{R}^{2}=0.88, \mathrm{~s}=1.75 \%$, DW $=1.74$

where $y$ is the log of national income in 1990 prices, $x$ is the log of exports of goods and services in 1990 prices and $\lambda$ is the log of the terms of trade. $\Delta$ denotes annual changes. The long-run solution of the model is:

$$
\begin{aligned}
& y=0.84 x+0.85 \lambda+1.01 \text { or } \\
& y=0.85(x+\lambda)+1.01 .
\end{aligned}
$$

12. The exchange rate is defined as an index of the Icelandic króna-price of foreign currency and measured in effective terms, with an increase in the index indicating a depreciation of the króna.

13. The annual vacancy rate is the average of the rates in April and September of each year, as the National Economic Institute has surveyed firms about their labour force plans during these months only. The average shown is thus only a rough measure of the "true" average. 
As summarised in Table 2, there have been five significant negative external shocks ${ }^{14}$ and to further help understand how these shocks influenced the inflationary process in Iceland we estimated a two-equation model on biannual data over the period 1970-1995 (see Annex A). We initially attempted to estimate a four-equation model but were not successful in identifying a reasonable exchange rate equation and the reaction function of the monetary authority is also missing. Nonetheless, even though the model does not tell the full story of how external developments feed into domestic prices, it clearly highlights the factors that can cause significant changes in the rate of inflation; viz. demand management and other forces that affect the unemployment rate; import prices measured in foreign currency; and the exchange rate policy with associated changes in the exchange rate. 15

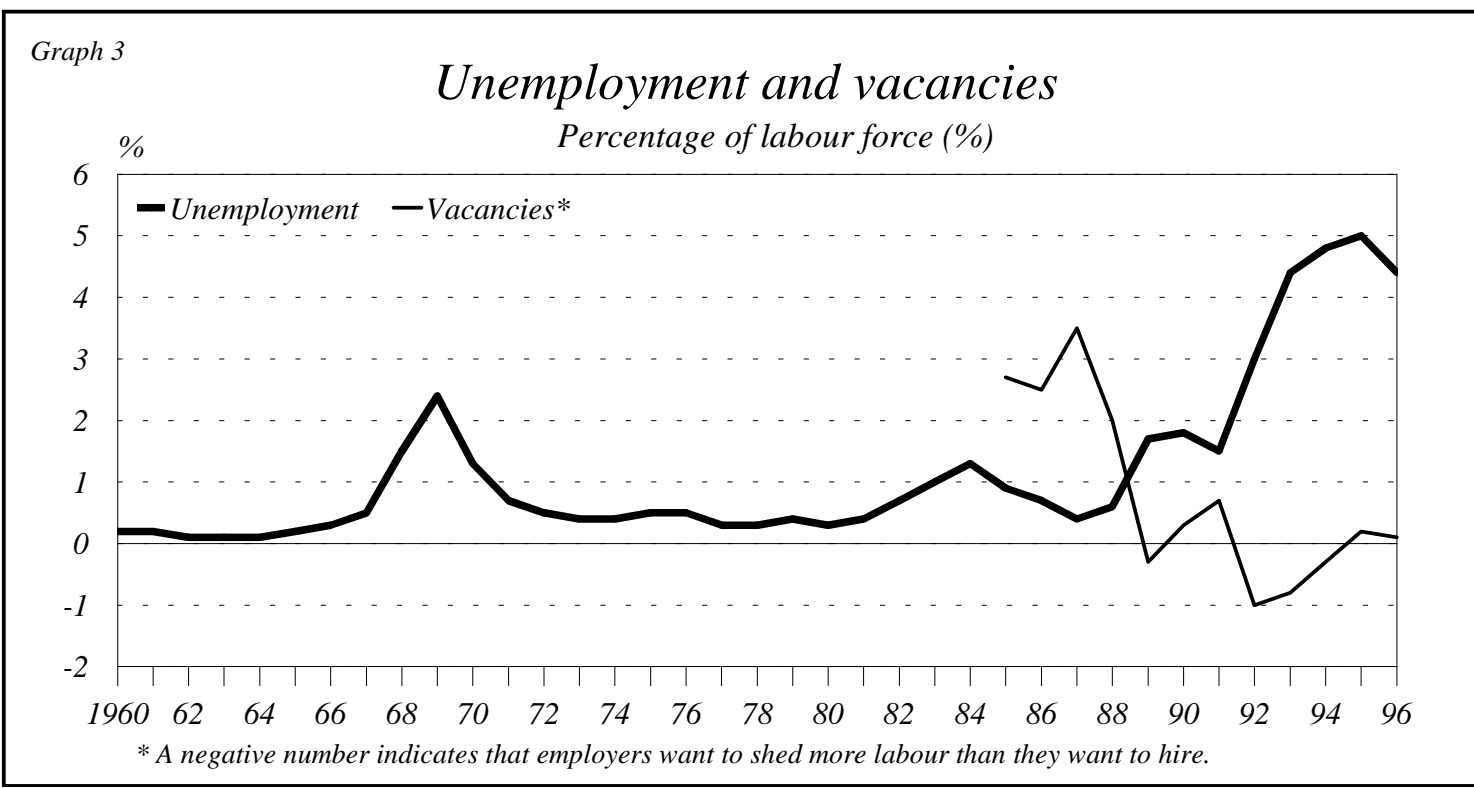

The price equation is a simple mark-up cost equation, where current price inflation depends on past price inflation, current and lagged changes in unit labour costs and current and lagged changes in import prices measured in domestic currency. As can be seen from the estimates, the sensitivity of domestic prices to changes in import prices and the exchange rate is very high in Iceland and because the authorities for most of the post-war period have relied on exchange rate devaluations as a means to keeping employment high, this has imparted a significant upward push to inflation. In fact, for the period 1980-85, when inflation averaged close to 50\%, depreciations may have contributed some $20 \%$ per year. ${ }^{16}$ The price equation does not contain any level variables and, therefore, does not explain the forces that shape the long-run development of the price level.

014. The purchasing power of exports also fell in 1995 , but only by $1.3 \%$. Moreover, since this episode was preceded and followed by positive external shocks it was excluded from Table 2.

15. We do not explicitly mention changes in productivity or in the terms of trade in this list as both are implicitly captured in the wage equation through changes in the factor income share. It is, though, clear that these variables can have and have had a significant influence, both directly and through their effect on the exchange rate.

16. Because depreciations in Iceland are likely to depend on the domestic rate of inflation, exchange rate movements should, of course, not be seen as exogenous. Rather, Iceland's history of inflation provides a good illustration of the "vicious circle" argument. 
Level variables, on the other hand, play a role in the wage equation, both through the factor income share of labour and the unemployment rate. In addition, changes in consumer prices have a significant influence on wages implying that a lower exchange rate or higher import prices have been gradually reflected in higher nominal wage gains, notwithstanding the initial absorption by wage earners of terms-of-trade losses induced by devaluations. Finally, indicating the accommodating stance of monetary policy and the full-employment policy pursued by the authorities through most of the post-war period, lagged changes in real money supply have also had a significant effect on wages. The estimated coefficient may actually incorporate another and more indirect effect, as the full employment policy made it quite safe for wage earners to push for nominal and real wage gains without fear of losing their jobs.

Although the estimates in Annex A are still tentative, the wage equation also allows us to address the question whether wage rigidities and indexation may have influenced the costs associated with reducing inflation. The evidence is ambiguous. On the one hand, since nominal wages respond to current and past price increases, real wages tend to rise in periods of decelerating price inflation and thus raise the costs of disinflation unless special measures are taken. On the other hand, the degree of wage flexibility, measured as the semi-elasticity of nominal wage changes with respect to the rate of unemployment (Table 8), is relatively high in Iceland, though also very sensitive to the level of unemployment. ${ }^{17}$ Moreover, nominal wage increases depend significantly on changes in the factor income share of labour and this influence helps to reduce the risk of disputes as to how employers or employees are to share the burden of disinflation. Of course, the income share term also means that nominal wages respond to changes in the terms of trade and that in periods of terms-of-trade improvements, nominal and real wage growth will accelerate. However, because Iceland's terms of trade have shown a trend decline during the post-war period, this reaction has, in fact, served to moderate wage increases and dampen the influence of external shocks.

We are now in position to weave these threads together and explain why inflation in Iceland went into the high range in 1974 and stayed there until 1984. First, there was the direct inflationary effect of the rise in import prices in 1974-1975, caused by the first oil shock and higher inflation in the world economy.

Secondly, as can be seen from Table 2, there was an increased frequency of negative external shocks. When the Icelandic economy was hit with the shock in 1967-1968, due to the collapse of the Icelandic-Norwegian herring stock, it had been nine years since the last negative shock. There were then six good years until the economy was hit with the shock of 1974-1975. Then shocks came with increased frequency; i.e. the second oil price shock in 1979-1980 and then in 1982 the fall in fish catches. ${ }^{18}$

17. As will be discussed later on, this may create a risk that the costs of reducing inflation will increase as inflation gets lower.

18. We checked whether relatively high output variability during the high inflation period could be an alternative explanation to the increased frequency of shocks. This, however, is not the case, as the standard deviation of output growth was actually the same during the high inflation period 1974-1983 (3.1\%) as during the disinflation period 1984-1995 and lower than during the period 1961-1973 (5.1\%). 
Table 2. Negative external shocks 1962-1996

\begin{tabular}{|c|c|c|c|c|}
\hline Periods & $\begin{array}{r}\text { Cumulative } \\
\text { \% change in } \\
\text { real export } \\
\text { revenue }\end{array}$ & $\begin{array}{c}\text { Number of } \\
\text { years since } \\
\text { last shock }\end{array}$ & $\begin{array}{l}\text { Inflation peak } \\
\text { by year and size }\end{array}$ & $\begin{array}{r}\text { Cumulative } \\
\text { depreciation \%* }\end{array}$ \\
\hline $1967-1968$ & -20.0 & 9 & $\begin{array}{ll}1969 & 21.7\end{array}$ & 50.0 \\
\hline 1974-1975 & -17.0 & 6 & $1975 \quad 49.0$ & 42.0 \\
\hline $1979-1980$ & -4.7 & 4 & 1980 & 46.5 \\
\hline 1982 & -9.7 & 2 & 1983 & 36.3 \\
\hline 1988-1992 & -13.6 & 6 & 1988 & 12.4 \\
\hline
\end{tabular}

* Measured from the last year before the shock to the inflation peak.

Thirdly, the devaluation bias seems to have become progressively stronger. This can be deduced from Table 2 by comparing the size of the shocks and the cumulative rate of depreciation from the last year before the shock to the year of the inflation peak.

Fourthly, the tight labour market and the institutions of wage formation were conducive to fuelling inflation. In particular, this applied to the widespread use of wage indexation, which is especially problematic when negative shocks are hitting the economy. ${ }^{19}$ There was also an element of pure wage push in the seventies, especially around $1974 .{ }^{20}$

The net result of these developments was that each successive shock in the seventies and early eighties led to successively higher inflation peaks. ${ }^{21}$ At the final peak in 1983, inflation was threatening to go into the extreme range. This prompted measures to drastically reduce the rate of inflation.

\section{The process of disinflation}

The process of disinflation in Iceland has taken place in two stages and each stage fits neatly into the experience of other countries as discussed in three recent studies. ${ }^{22}$

19. A dummy variable in the wage equation for the period of wage indexation until the first half of 1983 has a very significant positive coefficient. See annex A.

20. The biggest positive error in the wage equation without the indexation dummy occurs during the first half of 1974 and amounts to almost 8\%. Wage growth was also high during 1972 and 1973, with nominal unit labour cost increasing by $24 \%$ in 1973 and by $31 \%$ in 1974 . These wage increases were accompanied by significant gains in real earnings (16\% and 11/1/2\% respectively), whereas a 34\% increase in nominal unit labour cost in 1975 went hand in hand with a nearly $11 \frac{1 / 2}{2} \%$ fall in real earnings.

21. This process can be illustrated using the inflation equation which Bruno (1993) applies in analysing Israel's inflation and disinflation:

$$
\pi_{t}=\alpha \omega_{t}+\beta \varepsilon_{t}+(1-\alpha-\beta) \mu_{t}+v_{t}
$$

with $\pi=$ the rate of inflation, $\omega=$ the rate of wage inflation, $\varepsilon=$ the rate of exchange rate depreciation, $\mu=$ the rate of growth of the money supply and $v=$ a random error, including supply shocks. By subtracting the lagged rate of price inflation on both sides, the equation can be rewritten as:

$$
\pi_{t}-\pi_{t-1}=\alpha\left(\omega_{t}-\pi_{t-1}\right)+\beta\left(\varepsilon_{t}-\pi_{t-1}\right)+(1-\alpha-\beta)\left(\mu_{t}-\pi_{t-1}\right)+v_{t}
$$

An unfavourable supply shock $\left(v_{t}>0\right)$ causes an acceleration of inflation which is reinforced if wage indexation and full employment push up real wages $\left(\omega_{t}>\pi_{t-1}\right)$ and/or the real exchange rate depreciates $\left(\varepsilon_{t}>\pi_{t-1}\right)$ and monetary policy is accomodating $\left(\mu_{t}=\pi_{t-1}\right)$. Moreover, even in the absence of unfavourable shocks the system lacks a nominal anchor if wages and the exchange rate are indexed to past inflation and monetary policy is accommodating.

22. See Bruno and Easterly (1995) and Easterly op cit regarding the first stage and Dornbusch and Fischer op cit with respect to the second stage. 


\section{First stage of disinflation}

As mentioned earlier, inflation in Iceland has been well above that of other OECD countries throughout the post-war period. Moreover, the rate of inflation progressively accelerated to over $80 \%$ during the early 1980s. Following the 1982 external shock, the annual rate of inflation even reached more than $100 \%$ during the early months of 1983 and with the threat of even higher rates later in the year, a range of stabilisation measures were adopted in May. These included a temporary suspension of wage indexation (subsequently made permanent), ceilings on wage increases for the rest of the year, a policy of exchange rate stability (following an initial 15\% devaluation) and compensatory social security and tax changes to protect living standards. Despite the temporary nature of the incomes policy measures, the rate of inflation fell to about $30 \%$ in 1984 and more or less stayed at that rate over the next three years. Moreover, despite the contractionary policies, GDP growth accelerated to over 4\% following a 2\% fall in 1983 (see Annex B, Table 1).

Although the combination of disinflation brought about by stabilisation policies and higher growth looks unique and, at a first glance, counter-intuitive, the experience of Iceland during this first stage of disinflation is, in fact, common to many other countries which have disinflated from high initial levels of inflation. ${ }^{23}$ In reviewing the experience of six (mostly Latin American) countries in stopping high inflation, Végh (1992) finds that higher output growth is typically observed during the first one or two years after stabilisation, notably when a fixed nominal exchange rate is used as the principal nominal anchor. ${ }^{24}$ Bruno and Easterly op cit and Easterly op cit use another approach, based on "stabilisation episodes" defined as movements from inflation crisis periods (at least two years of inflation exceeding $40 \%$ per year) to non-crisis periods (at least two years of inflation below $40 \%$ per year). They find $26^{25}$ such episodes and the pattern of output typically shows gradually falling growth rates prior to the crisis, which become negative just prior to or during the year of peak inflation, but then turn sharply positive in the year immediately following stabilisation. A number of other developments or "stylised facts" in Iceland during this first stage are also typical of the countries in the samples considered by Bruno, Easterly and Végh:

- a swift recovery of private consumption, ${ }^{26}$ whereas investment typically picks up only two to three years after the implementation of stabilisation measures. Iceland deviates from this pattern, as there was a short-run resumption of investment growth, to be followed, however, by a

23. It is, of course, well known that hyperinflation can be eliminated rather quickly with virtually no costs to output and employment. Under hyperinflation, backward looking expectations are virtually absent and stabilisation policies introduced to stop hyperinflation enjoy a high degree of credibility; see Sargent (1982) and Végh (1992). The latter could suggest that to increase credibility the authorities might consider postponing the implementation of stabilisation policies until inflation has reached a level where it is the key concern of the population.

24. The growth experience of countries relying on a more stable exchange rate to reduce inflation, is often described as "recovery now recession later". In contrast, countries that mainly rely on tighter monetary policies, tend to experience an initial recession followed by recovery two or three years later. For further discussion see Calvo and Végh (1994).

25. While the experience of Iceland is mentioned in the text, it does not appear to be included among the episodes. On the other hand, all the country cases used by Végh are included. 
new slump;

- a gradual appreciation of the real exchange rate as prices of non-tradables only slowly converge towards the international rate of inflation and the rate of depreciation;

- rising trade and current account deficits due to the real appreciation and the pick-up in consumption; in some cases, these deficits have brought the stabilisation policies to a halt;

- a gradual decline in the growth of real money balances during the pre-crisis period, followed by renewed growth after stabilisation and the move to lower inflation (Graph 4);

- notwithstanding lower seigniorage revenue, a marked improvement of the fiscal balance, partly due to the measures taken and partly reflecting a reversal of the so called "Tanzi-effect". ${ }^{27}$ In the case of Iceland, however, the improvement proved to be only temporary. This is also the case in some the Latin American countries in Végh's sample leading several observers to conclude that fiscal consolidation is a necessary (though not sufficient) condition for a successful stabilisation programme;

- a marked rise in credit to the private sector, notably in countries adopting exchange-ratebased stabilisation policies. As argued by Khamis (1996), the fall in inflation may, in itself, be instrumental in increasing the demand for credit. ${ }^{28}$ When testing this hypothesis for Iceland we found some support but the data do not allow a separation of the effects of disinflation from those of financial deregulation;

- a sharp fall in nominal long-term interest rates but a higher real rate. More generally, the pattern of changes in real interest rates following stabilisation seems to depend on whether the programme contains one or more nominal anchors. In countries that rely exclusively on a fixed nominal exchange rate, real interest rates have tended to fall. In contrast, in countries, such as Iceland, that used a fixed exchange rate as well as incomes policies, real interest rates have tended to increase. This does not, necessarily, suggest that expectations of inflation adjust more slowly or that policies are less credible in these cases, but rather that the fall in inflation which can be ascribed to incomes policies is not regarded as permanent, possibly because such policies are often of a temporary nature. ${ }^{29}$

This last point could suggest that incomes policies might make disinflation more costly. However, this conclusion seems premature; in fact, one reason why Iceland, as well as other

26. Khamis (1996) and Detragiache and Harmann (1997) review various models that can explain the recovery of private consumption. For instance, inflation inertia may lead to lower ex post real interest rates and fiscal consolidation may be accompanied by positive wealth effects. Moreover, if consumers expect the stabilisation plan to fail they may increase current spending and reduce saving.

27. See Tanzi (1977).

28. Khamis finds supporting empirical evidence for Argentina, Chile and Mexico, but not for Israel. He also discusses various reasons for the rise in private sector credit, including a sharp fall in nominal interest rates and the associated "one-time debt rescheduling effect", a rise in the liquidity of the banking sector as the economy is "re-monetised" and "flight capital" returns and a general decline in uncertainty as the level as well as the volatility of inflation declines. $\mathrm{He}$ also argues that lower inflation may reduce banks' perception of default risks, but we regard this as less plausible. In fact, there have been several recent cases of non-financial enterprises as well as banks experiencing difficulties in adjusting to an environment of more stable prices.

29. A more extensive discussion of the slow adjustment of expectations of inflation, based on evidence from international financial markets, can be found in Gagnon (1996). 
countries relying on incomes policies, managed to substantially reduce inflation and, at the same time, saw a recovery in GDP and little change in unemployment might well have been that incomes policies combined with a more stable exchange rate initially helped to hold wage gains as well as the rate of depreciation below the past rate of inflation. ${ }^{30}$ To illustrate this argument, we use Bruno's inflation equation given above:

$$
\pi_{t}-\pi_{t-1}=\alpha\left(\omega_{t}-\pi_{t-1}\right)+\beta\left(\varepsilon_{t}-\pi_{t-1}\right)+(1-\alpha-\beta)\left(\mu_{t}-\pi_{t-1}\right)+v_{t}
$$

Hence, if incomes policies succeed in generating a fall in real wages $\left(\omega_{t}<\pi_{t-1}\right)$ and the real exchange rate appreciates $\left(\varepsilon_{t}<\pi_{t-1}\right)$ the first two terms will be negative and the rate of inflation will decline without enforcing lower wage inflation through tighter monetary policy $\left(\mu_{t}<\pi_{t-1}\right)$ and higher unemployment. ${ }^{31}$

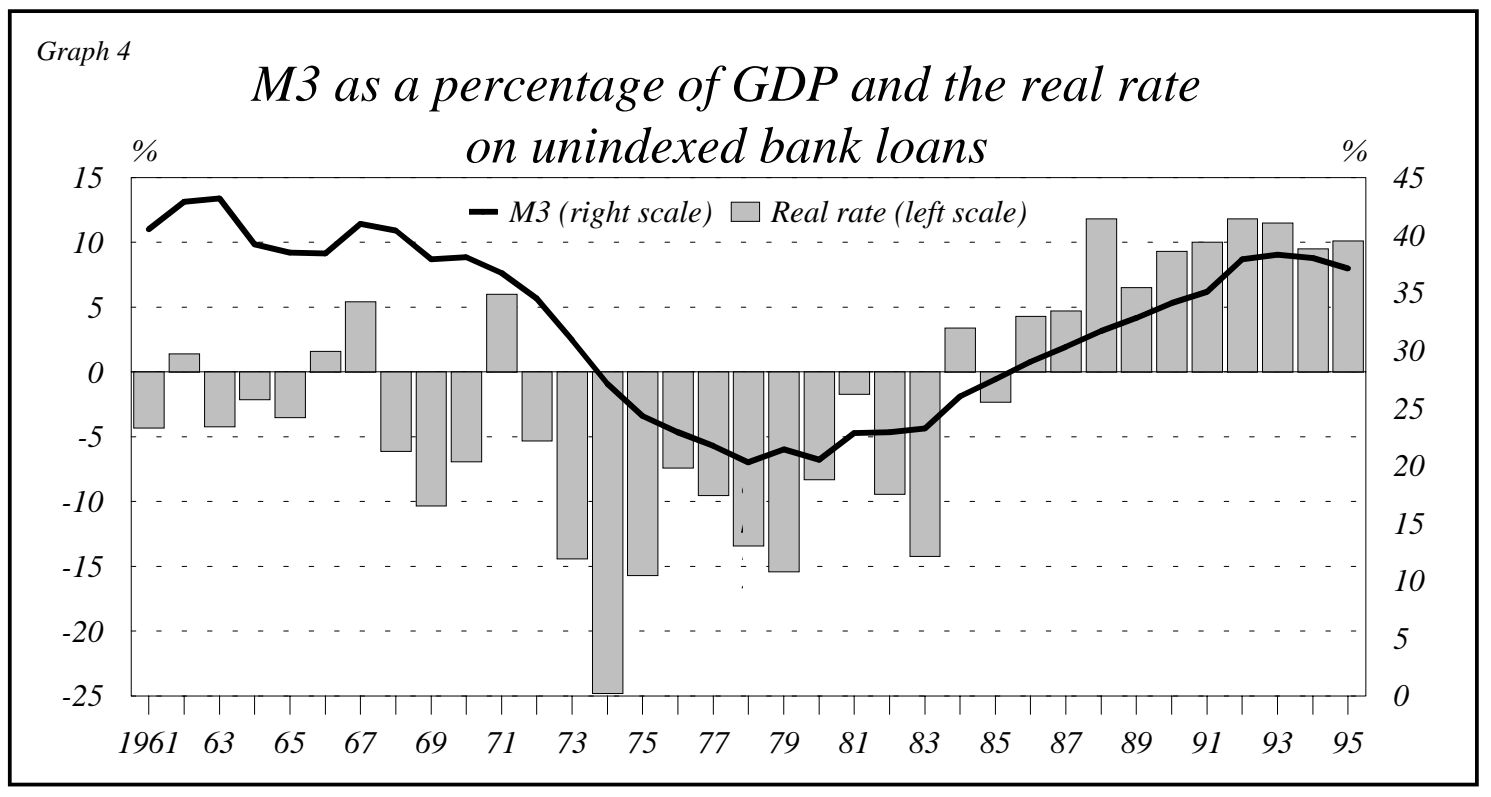

\section{Post-stabilisation period}

Wages increased sharply in 1985-86 (see Annex B, Table 1), mainly due to the temporary nature of the incomes policy measures but also reflecting very rapid output growth. The latter was sparked off by large terms-of-trade gains, reinforced by the deregulation of domestic financial markets. As a result, the currency had to be depreciated by $18-20 \%$ each year to prevent a real appreciation. Even so, the new and lower rate of price inflation was more or less maintained, but some of the adjustments and changes in the economy suggested that the more stable path might not be sustainable.

30. The experience of Italy during 1980-86 supports this view as incomes policy helped to reduce inflation by almost 15 percentage points while the rise in unemployment was well below that of other EU countries.

31. Using the methodology of the above equation, ignoring the money supply term but taking account of productivity and foreign inflation, we calculate that two-thirds of the fall in inflation between 1983 and 1984 can be accounted for by the wage term, while somewhat over one-third can be attributed to the exchange rate term. However, the contribution of wage moderation was equal to the exchange rate term over the whole first stage of disinflation from 1984 to 1987. These calculations use the relative weights of wage costs and import prices in the price equation in Annex A. 
Possibly as a result of the more stable exchange rate policy, firms absorbed part of the rise in wage costs in lower margins, leading to a marked fall in the share of profits. In fact, between 1984 and 1988, both the gross and net profit shares were reduced by about one-third (Graph 5). ${ }^{32}$ Despite the strong cyclical recovery, the fiscal deficit also increased significantly, pointing to a worsening of the structural imbalance.

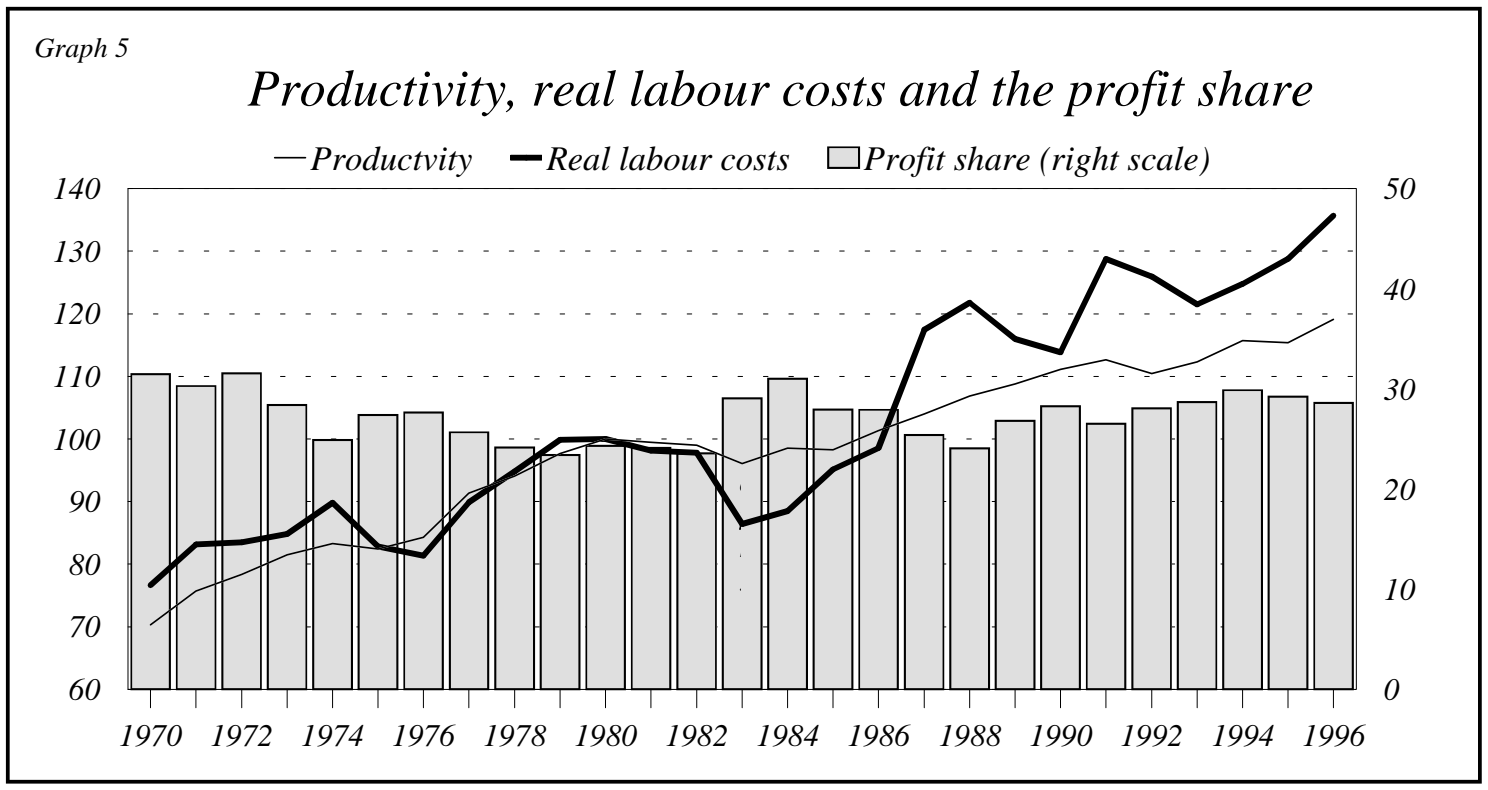

Moreover, influenced by several factors real interest rates rose to more than $10 \% .33$ The release of pent-up demand for credit, in combination with a partial removal of interest rate controls, tended to put upward pressure on interest rates, ${ }^{34}$ especially since exchange controls and restrictions on foreign capital flows were partly retained. In addition, a continued high financing need for the public sector and falling private-sector saving reinforced these pressures on domestic interest rates ${ }^{35}$ and even three to four years after the fall in inflation, expectations of inflation had not yet adjusted to the new and lower rate.

Finally, and similar to the experience of other countries relying on the exchange rate as the principal nominal anchor in reducing inflation, the rate of price inflation did not fall to that of the main trading partners. As a result, the competitive position deteriorated by more than $17 \%$ between 1984 and 1988, even though the rate of nominal depreciations remained relatively high. Combined with the rapid growth of domestic demand, this led to a further widening of the current account imbalance and a progressive build-up of foreign liabilities.

32. Due to the temporary wage freeze, the 1984 profit share may have been exceptionally high so that the subsequent fall was, in part, a return to more normal conditions.

33. Measured by the unindexed lending rate less the 12-month rate of inflation. Measured by the indexed lending rate the rise was less; see Annex B, Table 1.

34. This is a typical result of deregulating financial markets.

35. By 1987, gross national saving had fallen to $16 \%$ of GDP, compared with $23.5 \%$ in 1980 . Over the same period, the fiscal imbalance was reduced by less than $2.5 \%$ of GDP. 


\section{Second stage of disinflation}

The second stage of disinflation in Iceland took place during the early 1990s. In many ways it involved much more fundamental changes than the first stage and is more unique in an international context. The 1983-measures were mainly taken in response to a shock-induced inflation crisis and were similar to the so-called "heterodox"-programs that were adopted in many highinflation countries in Latin-America and in Israel during the middle of the eighties. ${ }^{36}$ The same can be said about the results as demonstrated above.

The second stage of disinflation differed from the first in several respects. First, although imbalances caused by severe overheating of the economy and adverse external shocks in the form of a renewed deterioration in the terms of trade and a lower fish catch did play an initiating role, the policy measures were not a response to a specific inflationary crisis. Secondly, the various policy changes were not confined to one specific stabilisation package imposed by the government; rather, they involved a sequence of events and responses. Thirdly, the new policies were to a large degree based on a consensus between the government and the partners in the labour market, whereas the 1983 stabilisation package had been imposed by governmental decree against, at least, verbal opposition from the labour unions. This consensus made the disinflation easier and possibly less costly; it was probably also instrumental in generating a moderate economy-wide wage settlement in February 1990 based on forward-looking expectations of inflation. ${ }^{37}$ Fourthly, the second stage contained a reorientation of policy priorities and strategies towards reducing inflation and keeping it low and away from maintaining full employment. Finally, it involved reducing inflation from a moderate level of $20-25 \%$ to below $3 \%$ which, historically, has proved to be much more difficult than reducing high inflation.

The Icelandic economy was hit by a "traditional" negative supply shock in 1988, as real export revenue contracted by $4.3 \%$. At the same time, the economy was suffering from the effects of a severe overheating in 1987 , when real earnings increased by nearly $20 \%$, employment by nearly $6 \%$, private consumption by over $16 \%$ and private fixed investment by around $20 \%$ (see annex B). The result was that the current account deficit rose to 31/2\% of GDP in 1987 as well as 1988 and both the real wage and output gaps widened significantly. Due to the overheating of the economy and the fixed exchange rate policy followed at the time, the real exchange rate increased sharply in 1987 and then peaked in 1988. These were conditions which, in the past, had prompted speedy devaluations in Iceland. The króna was actually devalued by $10 \%$ in May 1988, but that devaluation was quickly dissipated in a higher inflation rate and did not stop the real exchange rate from appreciating by over 5\% between 1987 and 1988 .

At this time, a fundamental shift in attitudes among the public at large towards inflation and in policy priorities of the government was taking place. The experience of the 1978-1983 inflation crisis and the widespread application of price indexation to household debt from the beginning of the eighties contributed strongly to this change of attitude among the public. The repay-

36. See, for instance, Végh op cit and Leiderman (1993).

37. The lack of consensus is probably less of a problem when dealing with an inflation crisis. 
ment burden of household debt had increased considerably after the suspension of wage indexation in May 1983 at the same time as financial indexation was being continued and inflation remained high. Along with the negative experience of high and variable inflation in general, this led to a growing awareness that the interest of households was best served by low inflation and stable economic conditions.

Shifts were also taking place in economic policy priorities, based on a progressively growing realisation of the need to correct the structural changes and imbalances discussed above and to remove the threat they posed to inflation stability. It was probably important in this regard that the 1983 measures had only in part removed the inflationary bias towards favourable as well as unfavourable external shocks, ${ }^{38}$ thus posing a continuous threat to the policy of keeping inflation low. ${ }^{39}$ Coinciding with these shifts was also the realisation that devaluations which are not supported by the stance of macroeconomic policies and/or by the necessary slack in the economy will have short-lived real effects and mainly result in higher inflation. ${ }^{40}$ Hence, one important part of the second stage was a significantly lower devaluation bias with the most visual effect of that reorientation being the fundamental change in the labour market that took place around 1989 (see graph 3). ${ }^{41}$

These various policy shifts all materialised when a new government took over during the autumn of 1988. Although a small devaluation in September 1988 of 3\% was part of the policy package presented by the new government, the main emphasis was put on the tightening of fiscal policy and on a statutory incomes policy, with a total wage freeze until February 1989. A large-scale rescheduling of debt in the traded goods sector was also part of the package, partly to reduce pressures in the export sector for a large devaluation. In fact, it was not until a new wage settlement had been reached in May 1989 that the króna was depreciated significantly and then, in the beginning of December 1989, pegged again to a trade weighted basket. However, by this time macroeconomic conditions had changed significantly as employment contracted in 1989 for the second year in a row, unemployment was reaching highs not seen since the economic crisis of 1968/69 and the positive GDP gap was greatly reduced. The result was that in 1990 the real exchange rate had fallen to a level not seen since 1985 and with a much lower infla-

38. Even though wage indexation was abandoned in 1983, the estimated short-run elasticity of nominal wages with respect to prices is as high as 0.6. Moreover, the coefficients of the price equation estimated in Annex A have remained stable, with the first-round price effects of the depreciations and increases in import prices during 1985-90 averaging more than $10 \%$ per year.

39. A vast majority of the countries in the 155 episodes of moderate inflation considered by Dornbusch and Fischer, came from low inflation and went back to low inflation, suggesting that moderate inflation does not usually degenerate into high or hyper inflation. However, this favourable "exit rate" probably suffers from a selection bias, as the fall in inflation, to a large extent, could be due to a timely implementation of stabilisation policies. In fact, there are only two countries (Columbia and Portugal) which have experienced more than ten consecutive years of moderate inflation.

40. The fact that nominal and real interest rates would respond differently to changes in the exchange rate following the removal of interest rate controls probably played an additional role in the reorientation of exchange rate policy.

41. There is also some econometric evidence that the determination of inflation and unemployment underwent structural changes during the second half of the eighties. Recursive estimates of the wage equation in annex A show that the unemployment term only became significant during the middle of the eighties and the real money supply variable during the early nineties. Gudmundsson and Zoega (1997) found a structural break in the expectations-augmented Phillips curve around 1988; moreover, unemployment became more sensitive to cyclical changes in output after 1987. 
tion peak than had usually accompanied such a fall in the real exchange rate during the high inflation period. As demonstrated in Table 3, the devaluation-bias had thus been greatly reduced, with the nominal devaluation during the 1988-92 shock much smaller in relation to the size of the shocks than during the high inflation periods and the "success"-ratio (i.e. the ratio between real and nominal depreciations) was also higher. Actually, both of these ratios were back to their levels of the late sixties and early seventies.

Table 3. Negative external shocks 1962-1996 and exchange rate behaviour

\begin{tabular}{|c|c|c|c|c|c|c|c|c|}
\hline Periods & $\begin{array}{r}\text { Cumulative } \\
\% \text { change } \\
\text { in real } \\
\text { export } \\
\text { revenue } \\
\text { (1) }\end{array}$ & $\begin{array}{r}\text { Inflation } \\
\text { peak, \% } \\
\text { (2) }\end{array}$ & $\begin{array}{r}\text { Year } \\
\text { of real } \\
\text { exchange } \\
\text { rate peak } \\
\text { (3) }\end{array}$ & $\begin{array}{r}\text { Year } \\
\text { of real } \\
\text { exchange } \\
\text { bottom } \\
\text { (4) }\end{array}$ & $\begin{array}{r}\text { Real } \\
\text { exchange } \\
\text { rate } \\
\% \text { ch. } \\
\text { (5) }\end{array}$ & $\begin{array}{r}\text { Cumu- } \\
\text { lative } \\
\text { nominal } \\
\text { depre- } \\
\text { ciation } \\
\text { (6) }\end{array}$ & $\begin{array}{r}\text { Response } \\
\text { ratio: } \\
(7)= \\
(6) /(1)\end{array}$ & $\begin{array}{r}\text { "Success" } \\
\text { ratio: } \\
(8)= \\
-(5) /(6)\end{array}$ \\
\hline 1967-1968 & -20.0 & 21.7 & 1966 & 1969 & -36.3 & 50.0 & 2.5 & 0.7 \\
\hline 1974-1975 & -17.0 & 49.0 & 1974 & 1975 & -21.9 & 36.1 & 2.1 & 0.6 \\
\hline $1979-1980$ & -4.7 & 58.5 & 1977 & 1980 & -11.6 & 63.3 & 13.5 & 0.2 \\
\hline 1982 & -9.7 & 84.3 & 1981 & 1983 & -13.9 & 65.3 & 6.7 & 0.2 \\
\hline 1988-1992 & -13.6 & 25.5 & 1988 & 1994 & -21.1 & 37.6 & 2.8 & 0.6 \\
\hline
\end{tabular}

Looking further ahead, the Icelandic króna was stable from December 1989 to November 1992, when it was devalued by $6 \%$ in the wake of the turmoil on European foreign exchange markets. This was the longest period of exchange rate stability of the króna since the early seventies. At the initiative of the government, the króna was devalued by a further $7.5 \%$ in June 1993, following decisions taken regarding allowable catches for the fisheries' year 1993/94, ${ }^{42}$ which implied cuts in the catch of many important species, especially cod. This was expected to lead to a $6 \%$ fall in the real value of the fish catch and to cause difficulties for the fisheries and the economy as a whole on top of the $9 \%$ fall in the price of marine products on international markets that had already taken place. Both of these devaluations occurred during a period of a slack in the economy and nominal wages did not respond. The inflationary effects of the devaluations were therefore short-lived.

To many in Iceland, the general wage settlement in February 1990 is seen as the main cause of disinflation during the nineties. That, of course, is an exaggeration, as macroeconomic policies and possibly structural measures as well had created the necessary underlying conditions for its realisation. The importance of the wage settlement in the whole process is, though, very large and it can easily be argued that the costs of disinflation would have been higher without it.

Table 4 below gives an overview of the private sector general wage settlements in Iceland during the nineties. In most cases, they involved more or less the whole private sector and were also, to various degrees, replicated in the public sector. As discussed in Section VII, the wage

42. The fisheries' year begins on 1st September and the government usually decides in May or June on total allowable catches of species subject to quotas. 
bargaining process in Iceland is highly centralised and the government is often involved, usually with fiscal concessions to promote wage moderation but also, sometimes, in trying to bring about the settlements. The government has also tried to increase the forward looking element in the settlements, mostly with declarations of exchange rate stability but, occasionally, by providing inflation forecasts as well.

The settlement in February 1990 involved most of the private and public sector unions. There were no significant fiscal concessions but the government promised exchange rate stability and lower nominal interest rates; this was, anyway, to be expected when the fall in inflation materialised. The settlement was for $1 \frac{1}{2}$ years, with CPI-thresholds that could trigger further wage increases. The outcome was in all cases close to these thresholds as wages increased by around $11 \frac{1}{2} \%$ in total during the contract period compared with an envisaged $101 / 2 \%$ rise. The most important element of this settlement was its forward looking nature as it involved an annual rate of wage increase of nearly $7 \%$ at a time when the 12-month rate of inflation was running above $20 \%$. It was the declared aim of the settlement to keep real wages constant during 1990 and then raise them during 1991. The role of leadership enters here in two ways. First, by convincing the labour unions that they should believe in inflation predictions rather than looking at past inflation. Secondly, by co-ordinating the process so that it became economy wide, which was a precondition for its success.

The settlements in 1992 and 1993 were based on the achievements of the 1990 settlement. But by this time the recession in the economy and growing unemployment were becoming serious concerns of the unions and had a significant effect on wage moderation, as can be seen in the table. The wage moderation in the 1993 settlement was, though, partly induced by a significant fiscal concession involving the reduction in VAT on many food items from $24 \%$ to $14 \%$. This level of wage moderation came to an end in 1995 even if unemployment peaked during that year. At that time there was a perception that the economy had started to pick up and hysteresis effects might, to some degree, have been setting in.

Table 4. Wage settlements during the first half of the 1990s:

\begin{tabular}{|l|r|r|r|r|r|}
\hline Date: & $\begin{array}{r}\text { Length in } \\
\text { years: }\end{array}$ & $\begin{array}{r}\text { Initial } \\
\text { wage } \\
\text { increase: }\end{array}$ & $\begin{array}{r}\text { Total } \\
\text { wage }\end{array}$ & $\begin{array}{r}\text { Fiscal } \\
\text { increase: }\end{array}$ & $\begin{array}{r}\text { Escape } \\
\text { clauses or } \\
\text { revisions }\end{array}$ \\
\hline Feb. '90 & $11 / 2$ & $1.7 \%$ & $10.5 \%$ & Yes, but small. & No \\
April '92 & 1 & $1.7 \%$ & $2.1 \%$ & CPI-thresholds \\
May '93 & $1 \frac{1}{2}$ & $0 \%$ & $0 \%$ & Yes: reduction in VAT & Yes: two reviews \\
Feb. '95 & 2 & $4 \%$ & $7 \%$ & Yes: income tax red. & Yes: review in Nov. 95 \\
\hline
\end{tabular}

Similar to the experience during the first stage of disinflation, the effects of the policy change were quickly seen (Graph 1 and Annex B, Table 2). Already by 1991 the rate of inflation (consumer prices) had fallen to less than $7 \%$ and by 1992, for the first time in thirty years, both output and consumer prices rose less than the OECD average. Moreover, the pace of nominal 
exchange rate depreciations was substantially reduced and yet the real exchange rate declined by $10 \%$ during 1989-94. Finally, the previous rapid growth in domestic credits and monetary aggregates was reined in by a more restrictive monetary policy. In other respects, however, the effects of the new policies were subject to longer lags. The fiscal deficit, following an initial decline, grew to more than $4 \frac{1}{2} \%$ of GDP in 1993-94 and the external imbalance was not removed until 1993. Moreover, the profit share, after some improvement in 1989-90, fell in 1991-92 (Graph 5), mostly reflecting exchange-rate-induced price constraints. Finally, real long-term interest rates, though easing slightly, stayed close to $7 \%$.

Graph 6 shows the development of inflation during the nineties together with the underlying developments in unit labour costs and the exchange rate depreciation. As the graph shows, wage moderation along with the stable exchange rate brought the rate of inflation down to $11 / 2 \%$ in the fourth quarter of 1992. The devaluations in November 1992 and June 1993 then temporarily boosted the inflation rate to a peak of $5 \%$ in the second half of 1993. During this period unit labour costs were not contributing to inflation and it, therefore, fell again as soon as the effects of the devaluations had worn off, bottoming out at $0.4 \%$ in the fourth quarter of 1994 . Since then increases in unit labour costs have been the major factor behind inflation along with some increases in import prices during the summer of 1996.43

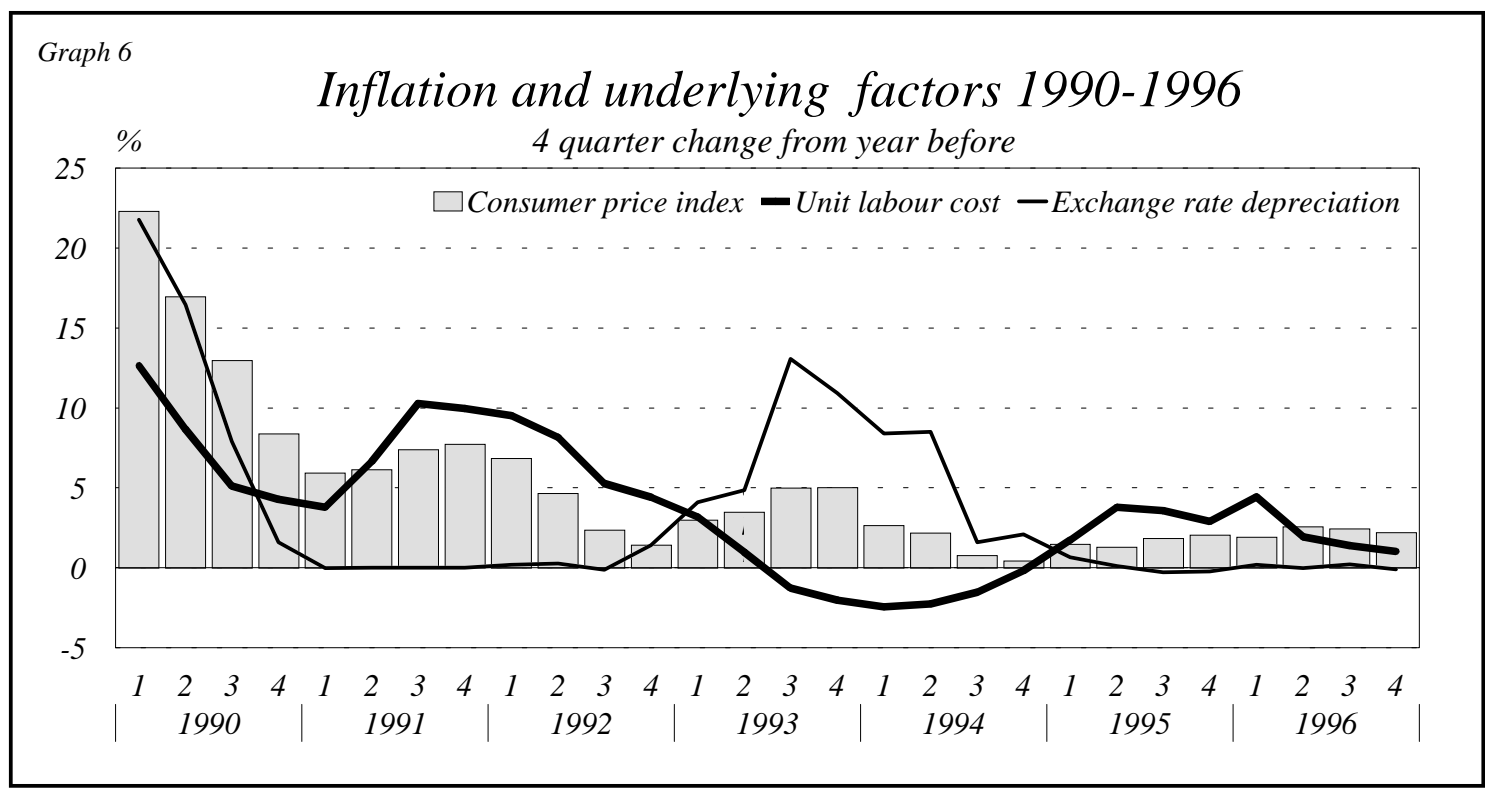

\section{Costs of inflation and disinflation}

Iceland's experience with inflation and disinflation raises several questions. First, what are the costs usually associated with high inflation and the effects of inflation and inflation uncertainty on growth? Secondly, did Iceland's high rate of inflation in the 1970s and 1980s adversely affect real growth and did the variability of inflation and the associated uncertainty further

43. Using the methodology of footnote 31 , it can be shown that the contribution of wage moderation was almost twice that of the exchange rate term. 
reduce output growth and raise the variability of output? Thirdly, were the costs, in the form of lower output growth and higher unemployment, of the policies of disinflation justified in the light of likely future gains? We shall attempt to answer these questions by first reviewing the literature on the costs of inflation and disinflation and then, in the following section, by comparing Iceland's experience with those of other countries that have also gone from moderate to low inflation. We stress, however, that given the complexity of these issues, we are not able to give precise answers to the questions posed. ${ }^{44}$

At a first glance it appears that the adverse effects of Iceland's previously high inflation were relatively small as long as inflation stayed in the "moderate" range of 15-30\%. However, this first impression is, obviously, pre-mature as growth might have been even higher and variability less if inflation had been lower and more predictable. Moreover the need to "suppress" the adverse effects through expansionary policies, including depreciation of the exchange rate and growing public debt, would also have been less.

In the literature, ${ }^{45}$ a distinction is usually made between the costs of respectively anticipated and unanticipated inflation, with the former assumed to be rather small and mostly confined to a tax on the holdings of currency ("shoe leather costs"), distortions due to the existence of tax systems and nominal contracts that are not fully indexed and increased relative price variability if firms set prices in accordance with menu cost models.

As regards unanticipated inflation, it is useful to distinguish between indexed and nonindexed economies. Starting with the latter, one obvious effect of higher inflation is a redistribution of wealth from creditors to debtors and of income from those with fixed nominal incomes to those with fixed nominal costs. A more serious problem is, perhaps, the misallocation of resources due to increased uncertainty, including a shift from nominal to real assets and a disincentive to invest in longer-term assets. This creates a risk that investment declines relative to output and that the composition of investment becomes sub-optimal. Investment decisions may be further distorted and the overall level of investment reduced if lenders respond to increased uncertainty by demanding higher risk premia and if lenders and borrowers have different expectations of inflation and of ex ante real rates of return. A further source of distortions and uncertainty is that, at higher rates of inflation, economic agents may become more uncertain about the preferences of the authorities and about the extent and timing of possible disinflationary measures.

In the case of a fully indexed economy, most of these costs and distortions will be significantly reduced, though not completely eliminated. Thus indexation is likely to inhibit desirable changes in relative prices and, thereby, to distort the allocation of resources. Moreover, excess demand tends to be transmitted more rapidly into higher prices and the overall rate of inflation will be higher if the anti-inflationary resolve of the authorities is reduced. Because indexation

44. Interested readers will find a more general discussion and empirical estimates in Gordon (1982), Chadha et al (1992) and Edey (1994).

45. A good review of the literature can be found in Briault (1995) and in Driffill et al (1990). 
makes it easier to "live with inflation", the incentive to disinflate is also less, especially if indexation is subject to lags and thus raises real wages when the current rate of inflation declines. Lagged indexation poses an even more serious problem when a fixed nominal exchange rate or a lower rate of depreciation is used as the principal means of disinflation, as it generates a real appreciation of the exchange rate.

Turning to the empirical evidence, there are several studies showing that both the variability of inflation (usually measured by the standard deviation or the year-to-year change) and the volatility of relative prices tend to rise with the average rate of inflation. ${ }^{46}$ However, in both cases the direction of causality is ambiguous. As mentioned by Briault op cit, variable inflation might induce risk-averse workers to ask for nominal wage increases that incorporate a risk premium for unexpected increases in inflation. Similarly, (Ball and Mankiw (1992) and De Abreu Lourenco and Gruen (1995)) more volatile relative prices tend to raise the average rate of inflation, especially when the expected rate of inflation is already high. It should also be noted that variability is not identical to uncertainty; in fact, inflation may be variable, but if the source of variability is well understood, it does not lead to more uncertainty. ${ }^{47}$

With respect to the effect of inflation on long-term growth, a consensus of numerous empirical studies would suggest that higher inflation has some adverse effect on growth but the estimated coefficients tend to be rather small and not very robust. ${ }^{48,49}$ Moreover, it is uncertain whether the relationship is linear or non-linear, though there is some evidence that the adverse growth effect is insignificant for low rates of inflation. ${ }^{50}$ Several studies have found that a lower investment to GDP ratio is the major channel through which inflation affects growth, probably reflecting the distortion to inter-temporal resource allocation due to higher uncertainty. However, given the marked fall in Iceland's investment/GDP ratio over the last 20 years, this distortion does not seem to have been present in Iceland even though investment decisions were also affected by many other factors, including deregulation of interest rates and financial liberalisation. It is also worth noting that in other countries with a disinflationary experience similar to that of

46. See, for instance, Hess and Morris (1996) and the references cited therein.

47. Some more recent studies have looked at the conditional variability as a proxy for uncertainty and generally found it to be positively correlated with average inflation over longer time horizons and when there have been changes in the trend rate of inflation.

48. See, for instance, Andersen and Gruen (1995), Andrés and Hernando (1997) and Levine and Remelt (1992). According to Andrés and Hernando, a 1 percentage point reduction in the rate of inflation might increase long-term growth in a typical OECD country by around 0.07 percentage point while Andersen and Gruen estimate a range between 0.025 and 0.1 percentage point. Applying the latter estimates to Iceland would suggest that the reduction of inflation between 1981-83 and 1984-86 increased long-run growth by 0.8 - 3.3 percentage point per year, while the disinflation between 1988-90 and 1991-93 boosted annual growth by $0.4-1.6$ percentage point.

49. Because of the high correlation between average inflation and the variability of inflation it is extremely difficult to identify their separate effects on growth (Judson and Orphanides (1996) is one of the few exceptions) and most empirical studies have looked at the relationship between inflation and average growth. Empirical work on the relationship between average inflation and the variability of output growth is also rare, though Hess and Morris (1996) report some preliminary evidence of a negative correlation.

50. According to Sarel (1996), the growth effect becomes insignificant for inflation rates below $8 \%$. On the other hand, Andrés and Hernando (1997) find that the (negative) elasticity of growth with respect to inflation is independent of the rate of inflation. 
Iceland, the fall in inflation has been accompanied by a marked decline in the investment/GDP ratio.

The likely costs of inflation provide only partial answer to the question, whether growth would have been higher and less variable if inflation had been lower. The costs of reducing inflation also need to be taken into account. We have already touched on this issue when looking at the two disinflationary episodes and shall return to it below. At this juncture it suffices to summarise some general findings:

- because the gains from lower inflation are permanent while the costs are finite, lowering inflation usually produces a net gain to society. ${ }^{51}$ However, if inflation adjust only slowly and there is a high degree of hysteresis in product and labour markets while the gains per year are only small, it may take a long period to realise a net gain; 52

- the speed with which inflation declines and output and employment return to their initial values is highly dependent on the credibility with which the stabilisation policies are received and on nominal and real rigidities in product and labour markets However, consensus estimates of rigidities and credibility effects are difficult to find;

- the costs of reducing inflation seem to be higher in countries with very independent central banks and credible monetary policies. One reason for this puzzling result might be that such countries are usually found at the "flat" part of the Phillips curve where nominal and real rigidities are high as price adjustments are infrequent (Ball et al (1988)) and wage contracts have a relatively long duration (Gray (1978)); 53

- opinions differ regarding the relationship between the speed with which stabilisation policies are implemented and their costs; some have found that a gradual implementation consistent with institutional factors tends to lower the costs (Taylor (1983)) while others argue that quick action is to be preferred (Ball (1993));

- finally, the costs of reducing inflation seem to be inversely related to the initial rate of inflation, with some suggesting that the costs become infinite (i.e. the Phillips curve is horizontal) at very low rates of inflation. ${ }^{54}$ In fact, one of the principal features of the second stage of disinflation in Iceland was that by 1989 Iceland faced the task of reducing a moderate rate of

51. Strictly speaking, this is not correct. In most theoretical models, the rate of inflation only affects the steady-state income level and not its rate of growth. However, since the adjustment period between two steady-states is 30-35 years in most studies, the distinction has little practical relevance.

52. Assuming a sacrifice ratio of 2.5 , an initial per capita income growth of $2 \%$ and a real discount rate of $5 \%$, Andersen and Gruen op cit find, that if lowering inflation by 1 percentage point increases annual output growth by only 0.025 percentage point, it takes over fifteen years to generate a net gain while for an output gain of 0.1 percentage point, a net gain is recorded after about six years.

53. Lucas (1973) arrives at a similar result, arguing that at low rates of inflation, firms tend to regard price and nominal shocks as shocks to relative prices which lead to larger adjustments of output. Posen (1994), however, does not find that nominal rigidities are higher in countries with independent central banks and according to Hutchison and Walsh (1996) and Bomfim et al. (1997) a more independent central bank or a higher degree of credibility could actually reduce nominal rigidities.

54. According to Akerlof et al (1996), a reduction of US inflation from the current rate of 2-3\% to near 0 may lead to a permanent rise in the NAIRU. 
inflation. As discussed in Dornbusch and Fischer, this tends to be much more costly than stabilisation policies in response to an inflation crisis. 55

Although the experiences of the countries discussed by Dornbusch and Fischer do not necessarily imply that the trade-off between output and inflation depends on the rate of inflation itself, we have attempted to illustrate the above point, using the menu cost price adjustment model proposed by Ball et al (1988). According to this model the frequency of price adjustments (and thus the overall rate of inflation) by monopsonistic firms tends to rise with the rate of inflation and when Ball et al test their hypothesis across countries they find supporting empirical evidence. In a more recent paper, Yates and Chappel (1996) test and reconfirm the model on an updated and revised cross-country sample, though they also detect some sensitivity to estimation methods and specification. The equation used by Ball et al and Yates and Chappel can be written as:

$$
x_{t}=a+b \Delta y_{t}+c x_{t-1}+d t+\varepsilon_{t}
$$

where $\mathrm{x}$ denotes real GDP, y nominal GDP (both in logs), $\mathrm{t}$ a time trend $\varepsilon$ a random error and $\Delta$ the first-difference operator. In the specific equation for Iceland, the trade-off coefficient () is estimated at $0.19-0.20$, compared with, for instance, $0.11-0.15$ for Ireland, $0.65-0.70$ for Denmark, 0.45 - 0.60 for Finland and an average value of $0.4-0.5$ for the 25 countries, for which significant coefficients were found. The rather low coefficient for Iceland, which is suggestive of low output costs associated with disinflation, is likely to reflect the comparatively high average rate of inflation. However, because inflation has been subject to large changes over the sample period used by Yates and Chappel (1941-91), the estimated average coefficient could be "masking" variations in the trade-off over different sub-periods. As a rough test of whether the trade-off has varied with changes in the rate of inflation, ${ }^{56}$ we reestimated the above equation, including a coefficient shift dummy for the period 1973-83, when inflation in Iceland was particularly high. The results are consistent with the above hypothesis, as we obtained the following equation (t-ratios in brackets):

$$
\begin{aligned}
x_{t}= & 0.83+0.33 \Delta y_{t}-0.13 D 73-83 \Delta y_{t}+0.76 x_{t-1}+0.90 t \\
\quad(2.7) \quad(4.2) & (2.5)
\end{aligned}
$$

Thus outside the 1973-83 period, about one-third of a change in nominal income is reflected in real output, while for the high-inflation period 1973-84 this ratio drops to $20 \%$. By the same token, stabilisation policies implemented during a period when inflation is already relatively low will have larger real output effects than when inflation is at its peak.

55. Burton and Fischer (1997) seem to take a different view, citing five countries (Chile, Egypt, Iceland, Kenya and Paraguay) that, on average, have managed to reduce moderate inflation without suffering any loss of output growth. However, their sample seems too small to justify more general conclusions and only two of the countries (Chile and Egypt) actually succeeded in both reducing inflation and maintaining or raising output growth.

56. The estimates by Ball et al as well as those in Yates and Chappel are based on cross-country data and we are not aware of any tests of the model on time series data for individual countries. 
However, in evaluating this result it needs to be taken into account that the apparently higher output costs during the second stage of disinflation could have been influenced by adverse external shocks. Thus real export revenue declined by over $81 / 2 \%$ during $1990-92$, mostly due to lower fish catches and adverse developments of the terms of trade. One possible way to assess this influence is to look at the error term of the equation for the growth of national income reported earlier where national income is explained by real exports and the terms of trade only. The cumulative error for the period 1990-94 is positive, indicating that the growth of national income was actually higher than could be explained by real exports and the terms of trade. Furthermore, there are small negative errors in 1990 and 1992 amounting to $0.3 \%$ each year. This seems to indicate that the bulk of the stagnation during the early 1990s can be explained by the adverse external shocks and that only a small part was due to the process of disinflation. However, it is possible that the negative effects on growth of occurred in advance the disinflation process; that is during 1988 and 1989, when the economy was being cooled down and prepared for disinflation. In fact, the error term in the growth equation is negative by 2- 21/2\% in both 1988 and 1989.

All in all, it seems fairly clear that Iceland's high inflation in the 1970s and 1980s adversely affected economic growth and economic performance and that the disinflationary measures taken were accompanied by net gains. The second stage of disinflation is more difficult to evaluate as it started from a lower rate of inflation and output growth was influenced by negative supply shocks. However, by comparing Iceland's performance to those of other countries that have also managed to reduce high or moderate inflation, it may be possible to get a clearer picture of the gains and losses.

\section{Iceland's comparative performance}

Argentina

Together with Iceland, Argentina is the only country in Easterly's (1996) sample which today has low inflation. ${ }^{57}$ In fact, Argentina has done even better as it has gone from hyperinflation to virtual price stability in the course of just five years, whereas Iceland did not move into the low-inflation range until 1991, eight years after the first stage of disinflation. How did Argentina achieve this and what were the costs?

Following an initial series of stabilisation measures during 1989-90, including a temporary freeze of the bilateral dollar exchange rate, privatisation and price controls, the principal policy

57. In annex $\mathrm{C}$ we list those countries on the IMF data tapes that have gone through a high inflation episode, which we define as annual inflation in excess of $30 \%$ over at least 3 years. In this list there are only four countries that in 1996 had an inflation rate of $3 \%$ or less; viz. Argentina and Iceland, which are also in Easterly's sample, and Bangladesh and Suriname which are not. Bangladesh experienced high inflation during the first three years after it gained independence (1972-74) while the high inflation episode of Suriname is of more recent date (1993-95). Both episodes are thus rather short-lived and related to a specific events, political in the case of Bangladesh and a combination of exceptionally loose policies, a massive depreciation of the currency and an extremely open economy in the case of Suriname. Consequently, the following comparison will be confined to Argentina, where the problems of high inflation have been much more serious and chronic. 
change in Argentina was the "convertibility plan", adopted in the Spring of 1991. The centrepiece of the plan was to fix the peso/US dollar exchange rate and to limit the amount of the monetary base to its equivalent in international reserves This essentially converted the central bank into a currency board and by abolishing its discretionary power to expand domestic credit it also forced the government to cut the fiscal imbalance. The plan was supplemented by a number of other measures and reforms, including further privatisation, tax and public sector expenditure reforms, deregulation of product, labour and financial, markets and liberalisation of foreign trade.

Table 5. Selective Macroeconomic Indicators: Argentina

In percentages or percentage changes, unless otherwise noted

\begin{tabular}{|l|r|r|r|r|}
\hline Items & 1990 & $1991-94$ & 1995 & $1996^{*}$ \\
\hline Real GDP (1) & 0.1 & 7.7 & -4.5 & 4.3 \\
Inflation (CPI) (1) & 2,314 & 40.6 & 3.4 & 0.2 \\
Unemployment (2) & 6.3 & 8.6 & 17.5 & 17.2 \\
Real wages (1) & -6.5 & -4.8 & -1.0 & -0.2 \\
Peso/US dollar & 0.558 & 0.996 & 0.997 & 0.995 \\
Real eff. exch. rate (3) & 100 & $178^{* *}$ & 169 & 167 \\
Real deposit rate & -78.5 & -11.3 & 3.5 & 6.7 \\
Current account (4) & 2.9 & $-4.1 * *$ & -0.9 & -1.4 \\
Fiscal balance (4), (5) & -3.5 & 0.4 & -0.5 & -1.9 \\
Gross Investment (4) & 14.5 & 17.8 & 19.0 & 19.5 \\
\end{tabular}

* Forecasts or estimates. ** End of period.

Notes: (1) Percentage change, annual rate. (2) In percentages of total labour force. (3) Index. (4) In percentages of nominal GDP. (5) Public sector net lending.

Sources: Inter-American Development Bank, Economic and Social Progress in Latin America; IMF, International Financial Statistics; Institute of International Finance, Country Reports.

In view of Argentina's earlier failures to combat inflation and stabilise the economy, the plan was remarkably successful (Table 5): (i) already by 1992, inflation had fallen to $25 \%, 58$ it "broke through" two digits in 1993 and for 1996 prices are estimated to have been largely stable; (ii) following several years of stagnating or falling output, real GDP started to expand shortly after the adoption of the convertibility plan and growth averaged almost 8\% during 1991-94; (iii) while the expansion was initially driven by consumption, fixed investment soon took over as the major engine of growth, with the investment/GDP ratio rising to nearly $20 \%$; (iv) the fiscal deficit has been virtually eliminated and the consequent reduction in lending to the public sector has allowed banks to expand credit to the private sector despite the limit on growth of the monetary base; and (v), reflecting the high degree of credibility in the plan, nominal as well as real interest rates declined substantially and inflows of private capital more than financed the current account imbalance.

Other developments, however, have been less favourable, even though Argentina's sacrifice ratio is well below those of the countries to be discussed below. Because, the adjustment of

58. Contrary to earlier stabilisation plans, the rapid deceleration of inflation was achieved without resorting to wage and price controls. 
domestic output prices to the exchange rate target was much slower than that of financial markets, the real exchange rate almost doubled, generating a negative swing in the current balance of payments equivalent to 7\% of GDP. Despite strong growth of output and stagnant real wages, the rate of unemployment increased to over $17 \%$, partly due to a rising participation rate but mainly as a result of firms paying much closer attention to their cost position in a low-inflation environment. Argentina was also adversely affected by contagion effects during the Mexican crisis in 1995 and was forced, temporarily, to suspend the 1:1 link between foreign reserves and the monetary base to counteract a liquidity crisis in the banking sector. ${ }^{59}$ However, by 1997 , the crisis appears to have been overcome and credibility to have been restored, except for some remaining fragility related to the poor quality of the loan stock of regional banks. On the other hand, even after the return to financial stability and higher growth, the problem of high unemployment remains and is starting to cause social unrest.

\section{Other industrial countries}

Table 6 compares Iceland to three other industrial countries, Ireland, New Zealand and Portugal, which, like Iceland, have managed to reduce a moderate rate of inflation to a level close to the OECD average. They are also rather similar with respect to the principal causes of inflation, whereas there are differences regarding the policy measures adopted and the time required (or taken) to reduce inflation. We first review the experience of each individual country and then attempt to find some common features and draw lessons for policies.

As noted by Walsh (1996), Ireland has for long enjoyed the unenviable reputation as an economic underachiever, but in the early 1980s the conditions of the economy gave more than the usual grounds for concern: the rate of inflation had reached almost $20 \%$, the fiscal deficit and the current external deficit were around $13 \%$ of GDP and the rate of unemployment had increased to $10 \%$ and was still rising. The main forces behind the acceleration of inflation from a low to a moderate rate were unfavourable supply shocks, combined with a high degree of real wage rigidity (see Table 8). Although Ireland had decided to break the traditional link to the British pound and join ERM at its inception in 1979, this step did not, initially, seem to provide any credibility gains to the process of disinflation (see Andersen (1992) and Dornbusch (1989)) or to have reduced inflation. In fact, during 1979-81 the currency was frequently devalued and it was not until 1982 that a more determined policy of disinflation and stabilisation was adopted. The principal measures were a marked tightening of both fiscal and monetary policy, with a view to correcting the fiscal imbalance and stabilising the exchange rate as a means to reducing inflation. The results were impressive: by 1987 the rate of inflation had declined to $2 \frac{1}{2} \%$, the fiscal imbal-

59. It is quite possible that the Argentinian economy would have weakened in 1995 even in the absence of the Mexican crisis. Thus the rate of growth progressively decelerated during 1994 and restrictive measures would probably have been required to reduce private demand growth and the widening current account imbalance. While this is similar to the 'expansion now, recession later' syndrome observed in other countries relying on a fixed exchange rate as the principal anchor, it is worth noting that inflation remained under control and the tight link to the US dollar was never an issue. 
ance amounted to only $1 \%$ of GDP and the external account was virtually in balance. However, the costs in terms of lost output growth and, in particular, higher unemployment were also large (Table 6).

A second phase of disinflation was launched with the Programme for National Recovery in 1987. While a firm exchange rate commitment and a tight fiscal policy remained the cornerstones of disinflation, they were complemented by an agreement with the trade unions to limit wage increases in return for tax concessions. Inflation remained stable around $2 \frac{1}{2} \%$ during this second phase, while unemployment started to fall and GDP growth accelerated sharply. In fact, since the late 1980s, Ireland (or the "Celtic tiger") has grown significantly faster than other EU countries, raising the question whether this is a late "reward" for reducing inflation.

A definite answer is beyond the scope of this paper, but some developments argue against this hypothesis: (i) even by mid-1996 real long-term bond rates, at 5-51/2\%, seemed to include a

Table 6. Comparative Indicators for Iceland, Ireland, New Zealand and Portugal

\begin{tabular}{|c|c|c|c|c|c|c|c|c|c|}
\hline Countries & Periods & $\begin{array}{r}\text { Infla- } \\
\text { tion }\end{array}$ & $\begin{array}{c}\text { Budget } \\
\text { balance }\end{array}$ & $\begin{array}{r}\text { Real } \\
\text { int. rate }\end{array}$ & $\begin{array}{r}\text { Exchange } \\
\text { rate }\end{array}$ & $\begin{array}{r}\text { Real } \\
\text { growth }\end{array}$ & $\begin{array}{l}\text { Unem- } \\
\text { ploym. }\end{array}$ & $\begin{array}{l}\text { Sacrifi } \\
\text { Unem. }\end{array}$ & $\begin{array}{l}\text { e ratios } \\
\text { Output }\end{array}$ \\
\hline \multirow[t]{3}{*}{ Iceland } & $1979-83$ & 57.5 & 0.6 & -9.8 & -4.6 & 3.0 & 0.6 & - & - \\
\hline & $1984-88$ & 25.3 & -1.3 & 4.4 & 6.1 & 4.4 & 0.8 & $\leq 0$ & $\leq 0$ \\
\hline & $1990-94$ & 6.1 & -3.6 & 10.4 & -4.2 & 0.7 & 3.1 & 0.37 & 0.90 \\
\hline \multirow[t]{3}{*}{ Ireland } & $1977-82$ & 15.1 & -11.8 & 0.3 & -0.8 & 3.8 & 8.8 & - & - \\
\hline & $1983-87$ & 5.5 & -10.1 & 7.0 & -0.7 & 2.3 & 16.1 & 1.85 & 1.45 \\
\hline & $1988-92$ & 3.0 & -2.6 & 6.2 & -2.0 & 4.8 & 14.8 & $\leq 0$ & $\leq 0$ \\
\hline New & $1982-87$ & 11.2 & -5.1 & 3.3 & 0.5 & 2.4 & 4.3 & - & - \\
\hline \multirow[t]{2}{*}{ Zealand } & 1987-92 & 4.3 & 1.5 & 6.6 & -2.4 & 0.4 & 8.2 & 1.80 & 0.85 \\
\hline & $1987-95$ & 3.3 & 1.2 & 6.5 & 1.1 & 1.9 & 8.1 & 2.70 & 0.50 \\
\hline \multirow[t]{3}{*}{ Portugal } & $1980-85$ & 22.5 & -8.5 & -3.5 & -0.5 & 0.8 & 8.0 & - & - \\
\hline & $1986-90$ & 11.5 & -5.5 & 3.5 & 2.7 & 4.5 & 6.3 & $\leq 0$ & $\leq 0$ \\
\hline & $1991-95$ & 7.5 & -6.5 & 5.5 & 2.7 & 1.7 & 5.1 & 0.50 & 2.90 \\
\hline
\end{tabular}

Notes: Inflation: Consumer prices, average annual rate; budget balance: general government net lending as a percentage of GDP, average for period; for New Zealand central government only; real int. rate: long-term government bond rate less rate of inflation. For Iceland nominal rate on unindexed bank loans less rate of inflation; for indexed government bonds the real rates for the three periods considered are 3.5, 7.8 and 7.5 respectively; exchange rate: real effective exchange rate in terms of unit labour costs (for Portugal, CPI), annual rate of change; real growth: real GDP, average annual rate of change; unemploym: number of unemployed as a percentage of the labour force, average for period; sacrifice ratios: figures in first column calculated as the cumulative change in the rate of unemployment over the period divided by the change in the rate of inflation (sign reversed); figures in second column calculated as the cumulative change in the ratio of actual to potential GDP over the period divided by the change in the rate of inflation (sign reversed); for Ireland and Portugal OECD data for potential output; for New Zealand potential GDP, proxied by a quadratic trend based on annual data (1960-95). For Iceland we derived two measures. The first is the HP filter given in Annex B (used in the table above) and the second a quadratic trend including a correction for changes in the fish catch and in the terms of trade which is shown below together with the equation for New Zealand. However, even though this second measure corrects for negative supply shocks, the sacrifice ratio, at 1.45, is actually higher than the one shown in Table 7. The 1996 OECD Survey of New Zealand presents two alternative measures of the output gap, both of which largely coincide with our own measure. In their study on potential output in Iceland, Herbertsson and Magnusson (1995) arrive at an average growth rate of 1.88\% for the period 1971-92, with capital input contributing $1 \%$, labour $0.2 \%$, externality effects $0.4 \%$ (essentially growth of human capital) and total factor productivity growth $0.3 \%$. However, this figure seems much too low as actual real GDP growth has averaged $4.0 \%$ ( $2.8 \%$ per capita) for this period.

\section{Estimates of Potential Output for Iceland and New Zealand}

\begin{tabular}{|l|r|r|r|r|}
\hline Countries & Intercept & Trend & Trend $^{2}$ & Pot. growth, 1990-96 $^{\text {New Zealand }}$ \\
Iceland & $2.36(9.8)$ & $0.0370(12.3)$ & $-0.0004(5.5)$ & $0.8 \%$ per year \\
& $0.97(2.7)$ & $0.0555(18.3)$ & $-0.0006(8.8)$ & $1.9 \%$ per year \\
\hline
\end{tabular}


significant risk premia compared with other ERM countries; (ii) as noted above, most empirical studies find that a higher investment ratio serves as a major transmission channel between lower inflation and higher growth. However, in the case of Ireland, growth has mostly been driven by consumption, whereas the investment/GDP ratio has fallen from nearly $30 \%$ in the early 1980 s to only around 15\% in 1994-95; and (iii) much of the growth in industrial output (which accounts for almost $40 \%$ of total GDP) and the turnaround in the foreign balance, as well, can be related to the transformation of manufacturing by attracting foreign "high-tech" companies through tax concessions and other subsidies. Output per employee in this modern sector is almost three times that of the traditional sectors and very rapid productivity growth (averaging over $7 \%$ per year) has helped to keep inflation low. 60

Adverse supply shocks reinforced by unstable policies and a high priority assigned to full employment were among the major factors behind the acceleration of inflation in New Zealand. A first attempt to stabilise the economy was launched in the early 1980s and this reduced the rate of inflation from 15 to about $7 \frac{1}{2} \%$. However, the relief was only short-lived. Due to the expiration of earlier wage controls and a marked rise in domestic demand growth, nominal wages accelerated sharply. Subsequently, when a foreign exchange crisis forced the authorities to abolish capital controls and float the exchange rate in 1984-85, a large depreciation of the currency reinforced the inflationary pressures, bringing inflation to a peak of over 17\% in 1985 .

A more determined effort started in 1987 and, in particular, in 1989 when the Central Bank was made fully independent with price stability (initially defined as an inflation rate in the range of $0-2 \%$ but last year widened to $0-3 \%$ ) as its only target. Although the inflation target has been the cornerstone of New Zealand's stabilisation policies, developments during the last ten years do not just reflect the process of disinflation but were also the result of wide-ranging deregulation and liberalisation efforts which have touched virtually all parts of the economy. Tax and expenditure reforms (eventually formulated in the Fiscal Responsibility Act of 1994) led to a marked tightening of fiscal policy and monetary policy was also kept restrictive to meet the inflation target. In contrast to the other countries in Table 6, New Zealand did not use the exchange rate as a nominal anchor; however, since 1992 currency appreciations have been a key instrument in keeping inflation low.

Due to the policies adopted, New Zealand achieved the inflation target sooner than initially foreseen. However, the costs were severe ${ }^{61}$ as total output stagnated between 1987 and 1992 and unemployment increased from 4 to over $10 \%$ of the labour force. Moreover, despite the independence of the Central Bank and the turnaround in the fiscal balance, credibility benefits are difficult to identify. Expectations of inflation did not adjust to actual rates of inflation until 1994 and long-term securities have been subject to a large risk premium, with real long-term interest

60. A general finding in the literature is that large sectoral differences in productivity growth tend to raise average inflation via wage spill-overs. Apparently, this has not been the case in Ireland.

61. See Debelle (1996) for an interesting comparison of the disinflationary experiences of New Zealand, Canada and Australia. 
rates almost doubling. Since 1992, however, real growth has accelerated to one of the highest in the OECD area, reducing the sacrifice ratio in terms of output as well as the rate of unemployment. However, possibly reflecting the fact that deregulation of the labour market came relatively late (Employment Contract Act of 1991), the sacrifice ratio measured in terms of unemployment is actually higher for the $1987-95$ period. ${ }^{62}$

In the case Portugal, the acceleration of inflation can be related to the political revolution of the mid-1970s and the subsequent sharp rise in nominal and real wages. The second oil price shock, combined with a relatively accommodating policy stance and a sharp depreciation of the exchange rate, reinforced the acceleration of inflation to a peak of over $28 \%$ in 1984 . Then a more restrictive policy stance was adopted aligned with a shift to more market-oriented policies. ${ }^{63}$ Together with a firmer exchange rate policy, following Portugal's joining the European Union in 1986,64 and a marked slowdown in nominal wages in response to weaker labour market conditions and incomes policies, the stabilisation policies reduced inflation to below $10 \%$. However, because the slowdown in output growth was rather short-lived, ${ }^{65}$ a second set of stabilisation measures was adopted in 1991 and, with the recession in Europe in the early 1990s, this helped to reduce inflation to only 3\% in 1996.

Although Portugal was forced to depreciate its currency during the European exchange rate crisis in 1992-93, the nominal exchange rate has continuously been relied upon as the principal nominal anchor. Incomes policies (in the form of tripartite national wage agreements) have also been applied but appear to have mainly reduced nominal wage growth in periods of excess demand; in fact, the major source of wage moderation appears to have been an unusually high degree of nominal and real wage flexibility (Table 8). ${ }^{66}$ The latter also helps to explain Portugal's very low sacrifice ratio in terms of unemployment, particularly when seen against the outputbased ratio (Table 6). ${ }^{67}$

Turning to some common features of the disinflation experiences and the lessons for policy, the following points are worth highlighting:

- independently of the type of policies pursued, all four countries have experienced a

62. In addition, deregulation of the labour market did not generate the hoped-for productivity gains so that the moderation of unit labour cost growth mainly reflects lower nominal wage gains.

63. One main feature of this shift has been the privatisation of publicly owned enterprises and banks.

64. Although Portugal did not join the EMS until 1992, annual depreciations of the escudo were substantially reduced after 1986.

65. Mainly because EU membership induced large capital inflows (notably direct investment) and a boom in domestic demand.

66. Portugal's relatively favourable labour market performance was probably also influenced by the fact that, unlike Spain, Portugal started the process of disinflation when the distribution of factor incomes was more or less in equilibrium. There are several reasons for the high degree of real wage flexibility in Portugal, including a rather wide sectoral dispersion of relative wages, measures to ease firms' lay-off costs and a low ratio of unemployment benefits to average wages combined strict eligibility criteria and a short compensation period. For further discussion, see Blanchard and Jimeno (1995).

67. It is also instructive to compare Portugal's employment performance and sacrifice ratios to those of neighbouring Spain. While both countries recorded inflation rates of 4-41/2\% in 1995, Portugal's unemployment rate was $7.2 \%$ compared with $23 \%$ in Spain. Moreover, Spain's sacrifice ratio during 1990-95 was about 10 when measured by unemployment and almost 12 in terms of lost output. 
marked rise in real interest rates and, despite the success in reducing inflation, long-term interest rates seem to contain a sizeable risk premia;

- as experienced by Ireland, Iceland and Portugal, small depreciations in response to external events (such as general exchange market turbulence) need not affect the credibility of exchange-rate-based stabilisation policies and help to prevent a real appreciation of the currency;

- depending on structural factors and the policies pursued, changes in real effective exchange rates have varied across the four countries. Portugal has seen a continuous real appreciation since joining the EU, though, in part, this may be a result of the initially low level of per capita income and subsequent catch-ups in prices of non-tradables. In the case of Ireland, real exchange rate changes depend importantly on the measure used. Due to rapid productivity growth in the "modern" industrial sector, the real exchange rate in terms of unit labour costs has depreciated (notably in the 1990s) while, in terms of consumer it appreciated during 1982-87 and then remained stable. New Zealand saw a marked real depreciation following the abolition of exchange controls but has lost competitiveness during the last five years as an appreciation of the nominal rate was used to meet the inflation target. As discussed earlier, Iceland experienced a real appreciation of the króna during the first stage of disinflation, whereas in the 1990s, when inflation had fallen to that of other OECD countries, competitiveness has improved;

- experiences also differ across the four countries with respect to recent trends of real output. Real growth in Ireland and New Zealand has exceeded growth in the OECD area by a wide margin during most of this decade, possibly suggesting that they are finally being rewarded for "good inflationary behaviour". However, New Zealand's growth rate declined to just over $2 \%$ last year and even though Ireland has continued to outperform other OECD countries, there is some doubt about the sustainability of the current growth path. In Iceland and Portugal, growth in the 1990s has been low by past standards and investment growth has also been rather moderate in Iceland. However, in both countries, temporary factors (respectively a low fish catch and a slump in major trading partners) have been significant, suggesting that low growth should not be seen as a permanent result of disinflation;

- when performance is viewed in terms of the unemployment-based sacrifice ratios, Iceland has done better than the other three countries, in particular, when compared with Ireland. However, Portugal has been almost equally successful, underlining the importance of real wage flexibility. By contrast, when the sacrifice ratio is measured in terms of lost output, Portugal has the least satisfactory performance, followed by Ireland, while New Zealand and Iceland have done about equally well. However, as noted in numerous studies, sacrifice ratios are not very precise measures and are highly sensitive to the length of the post-stabilisation period considered. For instance, in recent years Ireland has seen inflation falling in conditions of rapid output growth and an improving labour market; for New Zealand, the output-based measure declines whereas that based on unemployment rises when the measurement period is extended by two years; 68

- while there is large literature on the relative output costs of countries that have relied on 
either monetary policy or the exchange rate as the principal means of deflation, the experience of the four countries tends to show, that both restrictive macro-policies and a stable exchange rate are required to generate sustainably lower inflation. In addition, incomes policies may be important in reducing nominal rigidities and thus output costs at the initial stage of disinflation but seem to raise ex post real interest rates;

- none of the four industrial countries can match Argentina in terms of the speed of the disinflationary process. New Zealand may come closest due to the whole-sale process of deregulation over a relatively short period. However, unlike Argentina, New Zealand went through a long period of stagnation. The same applies to Ireland even though reforms were less extensive and hardly touched the labour market. Portugal's process of disinflation was probably the most gradual and this may be one more reason for the favourable labour market performance. Finally, the two-stage process in Iceland seems to show that the initial rate inflation rather than speed may be the most important determinant of the output costs.

We supplemented the indicators discussed above by looking at changes in inflation by contributing factor (Annex B, Table 3), but this did not reveal any major differences. In all cases, though most pronounced in Portugal, lower growth of unit labour costs was a key factor. Moderate growth of profits was also important, notably in Ireland and Iceland and in all four countries the process of disinflation was helped (or, at least, not made more difficult) by tax and subsidy measures. With regard to foreign trade prices, some variation in their contributions is apparent, as terms-of-trade changes have recently held back the process of disinflation in Ireland and Iceland whereas New Zealand and Portugal have benefited from external price changes.

\section{Specific features of the disinflation process in Iceland}

In this section we focus on two specific aspects, labour market flexibility and financial indexation, of the Icelandic economy and how they may have contributed to the process of disinflation and the costs involved. A third sub-section then looks at the role of fiscal and monetary policies in this process.

\section{Labour market and wages}

One remarkable feature of the disinflation process in Iceland is that unemployment remained below 1\% until 1988 and even at its peak in 1995 was significantly below the average for the rest of Europe. Although unemployment in Iceland is slightly understated by international standards ${ }^{69}$ and the favourable labour market performance has been significantly influenced by the full-employment policy pursued, this experience, nonetheless, suggests that there are aspects of the Icelandic labour markets which have created a high degree of flexibility and thus facili-

68. It is, however, possible that Table 6 understates the output-based sacrifice ratio for New Zealand, as the estimated trend rate is unusually low; cf. notes to the table.

69. Unemployment in Iceland only includes insured workers registering for unemployment benefits. However, even a broader measure does not change the impression of a very favourable labour market performance. In fact, the rate of unemployment for 1996, according to the definition used by ILO, is below the national measure; cf. OECD Economic Survey of Iceland, 1997. 
tated disinflation. The sources of this flexibility are analysed below, followed by a discussion of whether the rise in unemployment this decade could be a permanent effect of disinflation or is merely a transitory phenomenon.

\section{Sources of labour market flexibility}

The labour market in Iceland has several characteristics which are unusual by European standards and which may serve to buffer the effects of unfavourable external shocks. At over $77 \%$, the participation rate is significantly above the average for EU countries (66\%) and Icelandic workers also work very long hours, with many holding more than one job. Because the participation rate as well as the number of job holdings tend to change pro-cyclically, they help to dampen cyclical movements in unemployment and an additional shock absorber has been the Nordic Labour Market Agreement. In spite of Iceland's geographical position, net migration has both eased excess demand pressures in periods of rapid growth and served as an outlet for abundant workers during less favourable cyclical conditions. A further sign of a flexibility is the high degree of labour mobility. Thus regional differentials in unemployment have remained small in the face of quite large changes in the sectoral and regional distribution of employment, caused by a continuous decline in employment in primary industries (agriculture and fishing) and rapid growth in services, mostly concentrated in the capital area.

Institutional and legislative aspects have also enhanced labour market flexibility. Compared with other Nordic countries, the ratio of unemployment benefits to average wages is quite low, the period of entitlement relatively short and eligibility criteria rather strict. In addition, several characteristics of the wage negotiation process are worth highlighting:

- the unionisation rate, at more than $90 \%$, is the highest among OECD countries and with the employers' side also highly organised, general wage increases are typically determined within a nation-wide bargaining round. The government has frequently been actively involved in central wage settlements either through legislative measures or through tax and social transfer changes aimed at facilitating a low settlement. Consequently, as in other countries with highly centralised bargaining systems, Iceland has a wide scope for "internalising" distributional disputes as well as the macroeconomic effects and costs of the settlements, including their impact on price inflation and the share of profits;

- underlying this highly centralised framework is a decentralised system of sectoral or firmlevel negotiations and settlements. By allowing for specific sectoral conditions, these settlements have helped to prevent a freezing of wage differentials. However, they have also created a risk of "leap frogging" and of a consequently higher rate of rate wage growth, since sector-specific settlements usually come "on top" of the centralised settlement; ${ }^{70}$

70. A new legislation for industrial relations was adopted last year with the purpose of creating a more "orderly" system. Within this new framework the employers have proposed a two-stage bargaining structure with minimum wage increases to be decided in centralised settlements and productivity-based wage increases to be negotiated at the firm level. While such a system may help to strengthen productivity growth and could potentially increase relative wage flexibility, it remains to be seen whether it will also reduce the risk of wage-wage spirals and leap frogging. 
- the special bargaining procedure of the fishing industry provides a considerable degree of wage flexibility and a corresponding insurance against lay-offs as wages are partly determined by a revenue-sharing formula which ties wages to the fish catch and the prices obtained. However, it should be added that in periods of high profits in fishing it has also contributed to the wage-wage process mentioned above.

A final source of labour market flexibility may be that Icelandic firms are very small by international standards, as most enterprises employ only 4-5 workers. While this, of course, implies that very few firms achieve an "optimal size", it has probably helped to improve employer-employee relations as well as mobility and real wage flexibility.

\section{Empirical evidence}

Being a small and open economy that is highly dependent on revenue from a volatile industry (fishing), Iceland is, very exposed to external shocks. To prevent such shocks from adversely affecting employment and output in the rest of the economy, the need for flexible real wages is higher than in most other countries. Has this requirement been met?

From the various measures of volatility shown in Table 7, Iceland emerges as the country with the highest volatility of real output growth, with New Zealand and Finland, which are also subject to quite large terms-of-trade fluctuations, taking second and third place. While correcting for fluctuations in the fish catch and in the terms of trade reduces the volatility of GDP growth for Iceland, it is even more important to note that employment volatility is considerably lower than output volatility.

In theory, this may have two alternative explanations. On the one hand, it could suggest that because of various employment protection measures (for instance high lay-off costs and severance payments) firms are reluctant to adjust employment to variations in output. On the other

Table 7. Indicators of volatility: Various variables and countries

Standard deviations in percentages (1), unless otherwise indicated, annual data 1960-95

\begin{tabular}{|c|c|c|c|c|c|c|c|c|c|}
\hline Countries & $G D P$ & $\begin{array}{r}\text { Employ- } \\
\text { ment }\end{array}$ & $\begin{array}{r}\text { Produc- } \\
\text { tivity }\end{array}$ & $\begin{array}{r}\text { Real } \\
\text { wages }(2)\end{array}$ & $\begin{array}{r}\text { Real } \\
\text { labour } \\
\text { costs }(3)\end{array}$ & $\begin{array}{c}\text { Price } \\
\text { infla- } \\
\text { tion(4) }\end{array}$ & $\begin{array}{r}\text { Stand. } \\
\text { dev. }\end{array}$ & $\begin{array}{c}\text { Wage } \\
\text { infla- } \\
\text { tion(5) }\end{array}$ & $\begin{array}{r}\text { Stand. } \\
\text { dev. }\end{array}$ \\
\hline Iceland & 5.20 & 3.45 & 3.75 & 8.85 & 6.35 & 22.5 & 19.2 & 26.4 & 18.0 \\
\hline Ireland & 3.20 & 2.35 & 2.15 & 2.75 & 2.90 & 7.60 & 5.80 & 11.0 & 6.35 \\
\hline New Zealand & 4.40 & 2.40 & 3.90 & 3.90 & 3.85 & 7.45 & 5.75 & 9.35 & 6.70 \\
\hline Denmark & 2.60 & 1.75 & 2.50 & 4.75 & 2.75 & 6.25 & 3.55 & 8.50 & 3.90 \\
\hline Finland & 4.05 & 4.75 & 3.50 & 4.10 & 3.25 & 6.75 & 4.35 & 10.3 & 5.50 \\
\hline Norway & 2.35 & 2.85 & 1.90 & 3.40 & 4.75 & 5.90 & 3.05 & 7.90 & 3.60 \\
\hline Portugal & 2.45 & 2.95 & 1.95 & 3.50 & 4.90 & 5.90 & 3.05 & 7.90 & 3.60 \\
\hline Sweden & 2.50 & 2.85 & 3.85 & 4.55 & 3.90 & 6.75 & 3.40 & 8.80 & 3.15 \\
\hline
\end{tabular}

Notes: (1) Standard deviations after correcting for a quadratic trend, except for employment in Ireland, real wages and real labour costs in Iceland (linear trend) and real wages, real labour costs in New Zealand (no trend correction) and price and wage inflation (no trend correction). For Iceland, the volatility measures for GDP, employment and productivity would be reduced to 3.35, 3.10, and 3.05 respectively, if we also include a correction for variations in the fish catch and the terms of trade. (2) Compensation per employee deflated by consumption deflator. (3) Compensation per employee deflated by GDP deflator. (4) Average rate of price inflation (consumption deflator). (5) Average rate of wage inflation (compensation per employee). 
hand, it could also indicate that real wage flexibility acts as a buffer against external shocks. The fact that lay-off costs and redundancy payments are quite low in Iceland and that the volatility of productivity is less than that of output already argue against the employment rigidity explanation since, in the absence of any employment adjustment, the volatility of productivity growth would have exceeded that of output growth. A second reason for discounting the employment rigidity argument is the exceptionally high volatility of both real wages and real labour costs. This might, of course, be a sign that wages respond excessively to productivity growth and changes in the profit share but taking account of the wage arrangement in the fishing industry and our own estimates of the wage and price adjustment equations in Annex A, we are more inclined to believe that it reflects a willingness by wage earners to moderate real wage claims in conditions of severe supply shocks. In this context, it should also be pointed out that the volatility of real consumption wages exceeds that of real labour costs; i.e. real wages that workers receive are more flexible than firms' real costs of employing labour.

Turning to estimates of wage flexibility (Table 8), the estimates presented in Appendix A reveal a significant effect of the level of unemployment on nominal wage changes but no effect of changes in the degree of labour market slack when the wage equation is specified with error correction terms. ${ }^{71}$ It also appears that about one-half of a change in consumer prices is directly reflected in wages. This points to a rather high degree of nominal rigidity though this conclusion has to be modified in view of the highly significant error-correction term which suggests that, in the long run, wage earners adjust wage claims to maintain a stable share of total factor income. Moreover, the reaction to deviations between the actual and the "equilibrium" wage share is relatively fast, with over $30 \%$ being corrected within 6 months.

When applying the above estimates in evaluating the process of disinflation, it appears that the high degree of real wage flexibility helped to reduce the sacrifice ratio, especially during the first phase of disinflation. The rather slow and moderate reaction to changes in consumer prices (i.e. a high degree of nominal rigidity) would, normally, have increased the sacrifice ratio. However, for both stages of disinflation, this problem has been overcome through incomes policies, which "broke" the link between current wages and past inflation.

\section{Rising unemployment in the 1990s.}

Given these favourable features of the Icelandic labour market, an important question is why the rate of unemployment rose to over $5 \%$ this decade and whether this new level is likely to be a permanent consequence of the new low-inflation environment. Several factors may have

71. The wage equation estimated in Annex A is observationally equivalent to a long-run relationship where wage changes, inter alia, depend on changes in unemployment rather than the level. The OECD Economic Surveys of Iceland (1990 and 1991) present estimates of wage equations which also imply extreme hysteresis as wage changes are highly sensitive to changes in either real GDP or employment, while neither the level of unemployment nor output slack is significant. OECD further finds full pass-through of changes in consumer prices into wages, with about $70 \%$ occurring in the first year, an excessive sensitivity to productivity growth (coefficient of about 3 ) and a positive response to the lagged profit share and to current and lagged changes in the terms of trade. See also Andersen (1997) on the issue of hysteresis in the wage equation for Iceland. 
Table 8. Wage Flexibility

Selected countries and years

\begin{tabular}{|lr|r|r|}
\hline Countries & 1980 & 1985 & 1990 \\
\hline United States & 3.2 & 3.2 & 4.2 \\
Japan & 29.0 & 22.3 & 27.5 \\
Germany & 3.4 & 1.3 & 1.8 \\
Canada & 3.5 & 2.5 & 3.2 \\
Denmark & 2.7 & 2.1 & 2.0 \\
Norway & 11.8 & 7.7 & 3.8 \\
Sweden & 8.0 & 5.5 & 10.0 \\
Ireland & 2.6 & 1.1 & 1.4 \\
New Zealand & 1.8 & 1.4 & 0.6 \\
Portugal & 4.5 & 4.0 & 7.5 \\
Iceland & $\mathbf{1 8 . 0}$ & $\mathbf{6 . 0}$ & $\mathbf{3 . 0}$ \\
\hline
\end{tabular}

Note: Wage flexibility measured from a wage equation which, except for Iceland, was specified as: $\operatorname{dnn} w=\mathrm{a}-\mathrm{b} \ln u+\mathrm{c} \ln \mathrm{u}_{-1}+\mathrm{e}$ $\mathrm{d} \ln \mathrm{p}+\mathrm{f} \mathrm{dln}_{-} 1+\mathrm{g} \mathrm{z}$, with $\mathrm{w}=$ nominal wages, $\mathrm{u}=$ rate of unemployment, $\mathrm{p}=$ consumer prices, $\mathrm{z}=$ other variables and $\mathrm{d}$ the firstdifference operator. Flexibility is defined as: $\mathrm{d}(\mathrm{dln} w) / \mathrm{d} \ln w=\mathrm{du} / \mathrm{u}=(\mathrm{b}-\mathrm{c}) / \mathrm{u}_{\mathrm{i}}$, with $\mathrm{i}=1980,1985$ and 1990.

Sources: For Iceland (Annex A) and Portugal, authors' estimates; for other countries, Andersen (1992).

been influential in this respect, some of them permanent and others of a more temporary nature:

- in view of the poor labour market conditions in the other Nordic countries (except for Norway) and in continental Europe as well, the buffering role of net migration has been rather limited in the 1990s and may remain limited for some time;

- due to the fall in both inflation and in the rate of productivity growth and given past patterns of decentralised and sector-specific wage agreements, the scope for adjusting wage differentials has also been limited. Thus, if the aggregate change in nominal wages has to be consistent with the target of maintaining a low inflation rate and wage earners resist wage cuts, a relatively high rate of unemployment may be the only feasible way of obtaining the necessary reductions in relative wages in the less profitable sectors; ${ }^{72}$

- in the past, wage earners' attempt to maintain a stable share of factor income was probably a stabilising factor and their willingness to accept real wage cuts in the short run has clearly helped the process of disinflation. However, in the current environment of low productivity growth and worsening terms of trade, the distributional element in the wage adjustment equation may be more problematic and could have weakened firms' investment incentives and hence the prospects for job creation via addition to the capital stock. As can be seen from Table 9, average productivity growth has fallen from $3 \frac{1}{2} \%$ in the 1970 s to only $1 \frac{114}{4} \%$ in the 1990 s and the scope for non-inflationary increases in real wages has been further narrowed by worsening terms of trade. Consequently, even moderate real wage growth has not been sufficient to prevent the rise in real labour costs from exceeding productivity growth, with a resulting squeeze of profit margins and the share of profits;

- although investment is not determined exclusively by profits, it is, nonetheless, striking that parallel to the narrowing profit share, the ratio of investment to GDP has averaged less than

72. See Akerlof et al (1996) who find that reducing US inflation below $3 \%$ would lead to a permanent rise in US unemployment due to the downward inflexibility of nominal wages. 
$17 \%$ in the 1990 s, compared with $28 \%$ in the 1970 s and $20 \%$ in the 1980 s. As a result, it cannot be excluded that capacity shortages have contributed to the rise in unemployment; in fact, several recent empirical studies (Gudmundsson and Zoega (1996) and OECD (1997)) suggest that because of the slowdown in capital stock and factor productivity growth, the NAIRU for Iceland may have increased to around $4 \%$. Moreover, the fact that the recovery in GDP growth last year virtually closed the output gap when the rate of unemployment was still $4 \frac{1}{4} \%$ and was accompanied by wage pressures would support these recent estimates of the NAIRU;

- a related issue is the perennial balance of payments deficit and the relatively high level of foreign debt. ${ }^{73}$ A return to earlier policies of devaluing the currency does not seem to be the appropriate solution to this problem as the costs in terms of higher inflation are likely to outweigh the gains in net export growth, given rather low price elasticities of exports and imports. Instead, policies to strengthen national saving seem to be called for. Between 1970 and the trough in 1991, national saving as a percentage of GDP fell from 26 to only 14\%, more than half of which was due to lower private saving. Since the trough in 1991, national saving has increased to around $16 \frac{1}{2} \%$ of GDP, mainly owing to higher corporate saving while household saving has been stable and government saving, despite some recent strengthening, has fallen further. At around $10 \%$, household saving in Iceland is not low compared with rates recorded in other Nordic countries and in North America but a large part of it seems to reflect the servicing of mortgage debt. Moreover, given the return to balance of payments deficit last year, corporate and government saving are clearly too low to finance any major increase in the capital stock.

Table 9. Developments in Productivity, Real Wages and Profits

Percentage changes, annual averages

\begin{tabular}{|l|r|r|r|}
\hline Items & $1970-80$ & $1980-90$ & $1990-96$ \\
\hline Productivity & 3.6 & 1.0 & 1.2 \\
Terms of trade & 0.2 & 0.0 & -1.2 \\
Real labour costs & 2.7 & 1.3 & 3.0 \\
Real wages & 3.1 & 0.6 & 2.7 \\
Net profits & 12.2 & 16.2 & 15.7 \\
\hline
\end{tabular}

Notes: Productivity: real GDP/employment; terms of trade: export prices/import prices; real labour costs: compensation per employee/GDP deflator; real wages: compensation per employee/consumption deflator; and net profits: net operating surplus/GDP, in percentages, end of period.

All in all, the points mentioned above suggest that equilibrium unemployment (or the NAIRU) in Iceland has permanently increased, possibly to around 4\%. However, this does not necessarily imply that the costs of disinflation were too high. First, much of the rise in the NAIRU is not due to lower inflation but to the low level of national saving and investment and the resulting slowdown in capital stock growth. Secondly, experience from other countries shows that the gains from lower inflation are subject to long lags and, in the case Iceland, the gains

73. If the NAIRU were defined as the level of unemployment consistent with equilibrium on the balance of payment, it would be significantly higher than 4\%; see Andersen (1997) 
have, temporarily, been offset by negative external shocks. Thirdly, further gains from the low inflation environment may be dependent on other policy reforms, including wider scope for changes in relative wages to reduce nominal wage rigidities as well as measures to improve competition in product markets and the cyclical sensitivity of prices.

\section{Financial indexation}

Another special feature of the Icelandic economy is the use of indexation, not only in wage contracts but also in financial assets and liabilities. Given the mixed views of the usefulness of financial indexation in the literature, we next turn to financial indexation in Iceland and its possible influence on the process of disinflation. It is well documented in the literature that ex post real interest rates tend to rise significantly in the aftermath of disinflation programs. Végh (1992) estimates ex post real interest rates of several hundred percent in the wake of the disinflation programs that were adopted in several Latin-American countries and in Israel in the middle of the eighties. ${ }^{74}$ Real interest rates also rose to rather high levels in many industrial countries, following the reduction in inflation during the eighties.

Kaminsky and Leiderman (1993) attribute this phenomenon to ex post errors in inflation expectations due to the lack of credibility of the disinflation programs. Other explanations have focused on the shortage of liquidity induced by contractionary monetary policies. ${ }^{75}$ Kaminsky and Leiderman test their hypothesis on data from the stabilisations in Argentina, Brazil, Israel and Mexico during the middle of the eighties and find supporting evidence.

It can be argued that this phenomena does not matter that much for the costs of disinflation as it is the ex ante rather than the ex post rate that determines economic decisions and the ex ante rate does not rise due to errors in expectations as does the ex post rate. The main criticism of this argument is that it ignores the real transfer of resources implied by high ex post rates, which will affect borrowers' behaviour and could even lead to bankruptcy.

\section{Financial indexation in Iceland}

One principal characteristic of the Icelandic financial market is the extensive use of indexation and its long history. A high and variable inflation rate along with controlled nominal interest rates were the main impulses to its widespread adoption. In the 1970s, the combination of high inflation and interest rate controls had resulted in highly negative ex post real interest rates which caused a significant fall in financial saving and widespread disintermediation. The ratio of M3 to GDP fell from about $40 \%$ at the end of the 1960 s to just over $20 \%$ by 1978 , when real rates of interest were around $-20 \%$.

Limited financial indexation in Iceland dates back to 1955 and on government bonds to 1964. Financial indexation did, however, not become dominant until 1979 when the credit-terms

74. Mexico is the exception as the estimated ex post real rate "only" went as high as $52 \%$ after the 1987 stabilisation program.

75. See, for instance, Dornbusch (1986). 
index, based on available price-indices, ${ }^{76}$ was introduced. In that year, banking institutions were authorised to index their lending, and the following year indexation was extended to include deposits. Initially the minimum period for deposits to be tied before indexation applied was two years, but this was reduced to three months in 1982, in the wake of growing reluctance to raise nominal interest rates in line with price developments. Indexed deposit accounts enjoyed great popularity from the outset and contributed to reducing the outflow of funds from the banking system.

On the whole, financial indexation has been highly beneficial in Iceland. It reversed the trend of falling financial saving and disintermediation and thus created the basis for the development of capital markets later in the 1980s. It made it possible to develop fairly long-term forms of lending and financial instruments. It also saved the Treasury interest expenses, especially after domestic interest rates had been fully liberalised, as inflation risk premia on longterm government bonds would have been rather high. Finally, it played a beneficial role in the disinflation process. The main problems with financial indexation have been associated with interest rate formation at the short end of the market and risks in the banking system due to imbalances between indexed assets and liabilities.

Although some steps have been taken to reduce the scope of indexation at the short end of the market, it is estimated that, at the end of $1995,95 \%$ of the stock of market securities was inflation-indexed, $51 \%$ of deposits in the banking system and $51 \%$ of bank lending. It is also worth noting that, at $91 \%$ at the end of 1996, the bulk of household debt is indexed as well.

\section{Inflation-indexed bonds}

There is a growing literature on inflation-indexed bonds. Price (1997) gives an excellent survey and Barone and Masera (1997) discuss the pros and cons of index-linked bonds. Lately, the discussion of financial indexation has been greatly influenced by the relatively recent issue of index-linked bonds in industrial countries that are not suffering from high inflation, such as the United Kingdom, Canada, Australia, New Zealand, Sweden and, most recently, the United States. The main arguments in favour of indexed-linked bonds that we see emerging from this literature and the experience are: market completeness, increased incentives to save, promoting the development of capital markets, distributional benefits, reducing the costs of government borrowing, stabilising the real cost of borrowing over the cycle and aiding the implementation of monetary policy.

In the past, the strongest objection against index-linked bonds was that they are an instrument for living with high inflation and could, therefore, undermine the will to reduce inflation. That in turn will have unfavourable effects on inflation expectations and policy credibility. This argument seemed to be born out in practice as the introduction of index-linked bonds was usu-

76. Initially, the credit terms index, was a weighted average of the CPI and the building cost index. In 1989 the wage index was added to the average but from 1995 the credit terms indexed is solely based on the CPI with a one month lag. 
ally associated with high inflation countries. The force of this argument is somewhat less these days as more low inflation countries have started to issue index-linked bonds. There is also the counter-argument that if the government issues indexed bonds in significant amounts, that in itself will reduce one of the incentives to inflate.

It is interesting that the Icelandic experience does not support these arguments as inflation was reduced to very low levels only after the introduction of widespread financial indexation. Steps have been taken lately to reduce the scope of indexation, but only after the goal of low inflation had been reached. ${ }^{77}$ The argument has actually been made that financial indexation might have contributed to the consensus for low inflation which gradually built up in Iceland during the late eighties and early nineties. ${ }^{78}$

\section{Inflation expectations}

The available evidence indicates that inflation expectations were higher than actual outcomes during the whole disinflation process in Iceland. There are two pieces of evidence available on this. First, sample surveys taken two to four times per year during the period 1984-1993. Secondly, annual forecasts made by company chairmen for 1991-1997. We will concentrate the analysis on the first set of data as it has a higher frequency and covers a longer period, which makes an econometric analysis more meaningful. But it can be mentioned that forecasts of company chairmen overpredict in all years. For instance, the prediction for 1994 was nearly 4\% whereas the outcome was $1 \frac{1}{2} \%$.

In the sample surveys, people are asked what they think the rate of inflation is going to be during the coming twelve months. These expectations are shown in Graph 7, along with the outcome and the expectational errors. It clearly shows that expected inflation was more or less consistently above actual inflation when inflation was falling. The data on inflation expectation are analysed more formally in annex $\mathrm{D}$. The main result is that the simple model of rational expectations is rejected. On the other hand, the data are consistent with adaptive expectations and/or with rational expectations combined with uncertainty about whether the government really wants to stick to the disinflation course; i.e. that there is a problem of credibility. With some simplifying assumption it appears that the public only attaches a probability of $10 \%$ to the event that the government is really serious about low inflation. Anyhow, it is clear from the data that, as late as in October 1993, inflation expectations had not nearly adapted to the new low inflation environment, due to either their backward-looking nature or lack of credibility.

\section{Ex post real interest rates}

As noted above, Iceland shared the experience of many other countries, which have reduced inflation from chronically high rates, that inflation expectations for a considerable period

77. Price (1997) seems to misunderstand this sequence of events, even hinting that de-indexation had a role in the disinflation process, which it did not.

78. See Guðmundsson (1994). These arguments were also made in the section on the second stage of the disinflation process. 


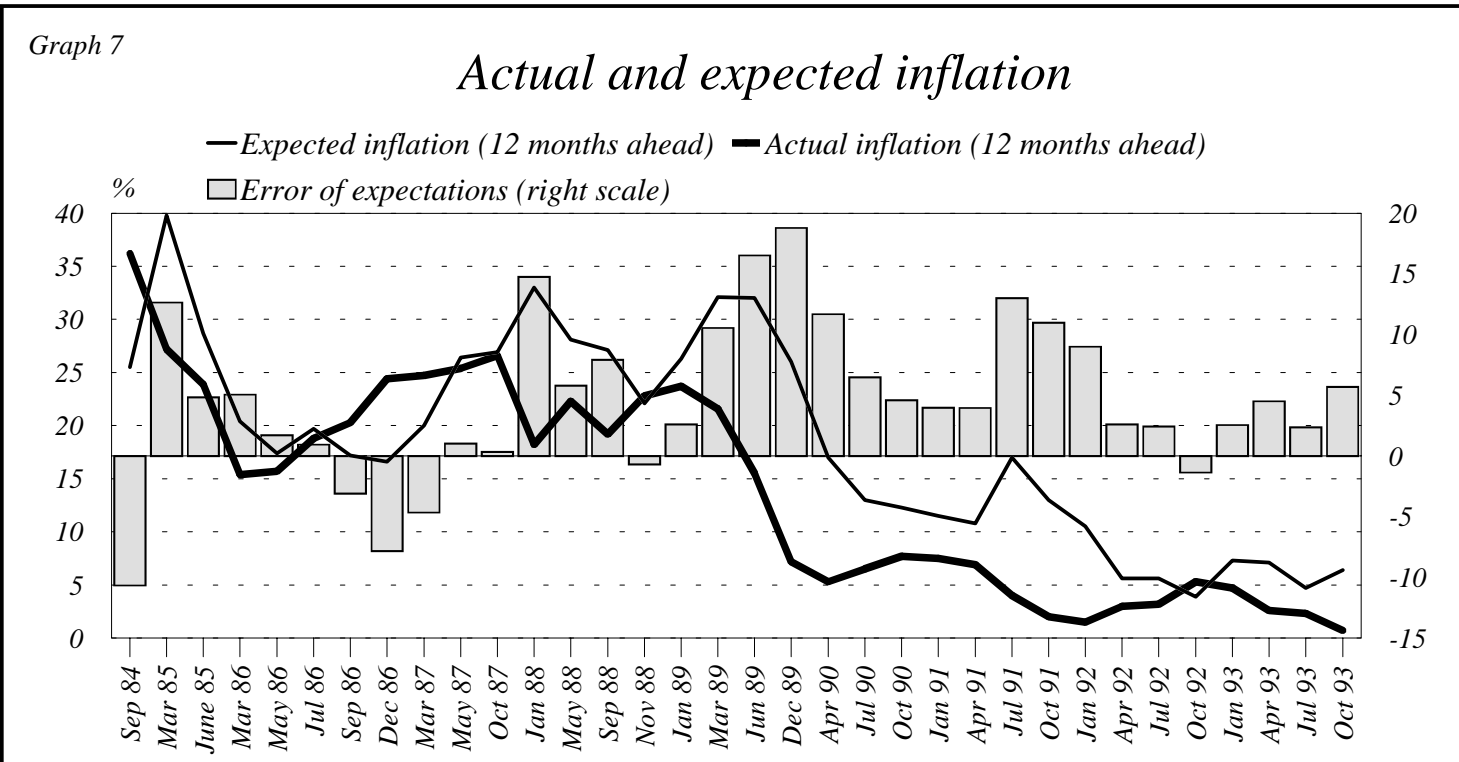

remained far above the actual rate of inflation, with expectational errors going as high as $19 \%$. Potentially, this could have led to very high ex post real interest rates. The reason that this did not happen to the degree that might have been expected was probably the widespread use of financial indexation. Unindexed bank loans did exist but they were relatively short term, ${ }^{79}$ with interest rates determined with reference to the dominant indexed rates by adding an inflation forecast which was often much closer to official government forecasts than to inflation expectations of the public. Graph 8 shows the development of real interest rates on government bonds and bank loans, on the one hand, and unindexed bank loans, ${ }^{80}$ on the other, during 1980-1995. Although it has to be born in mind that bank interest rates were not liberalised until 1984-1986, the graph seems to indicate that there was some increase in ex post real interest rates in the aftermath of the 1983 disinflation program. This, however, was not nearly of the scale experienced in many other countries that have disinflated from high inflation. It was also mitigated by widespread financial indexation as can be seen from developments in rates on indexed loans and securities. While real interest rates increased significantly during 1987 and 1988 and have remained high in Iceland since then, this is to be attributed to the effects of financial liberalisation in 1986 and 1987 and to the strong overheating of the economy in 1987 and 1988. The picture does not reveal any major direct effects on ex post real interest rates from the disinflation of the early nineties.

\section{Costs of disinflation}

A final question is whether ex post real interest rates matter for the costs of disinflation, as long as ex ante rates are not affected. According to standard macroeconomic models it should be ex ante rates that matter for investment and consumption decisions. But changes in ex post rates

79. Usually less than three years

80. The ex post real rate on unindexed bank loans are here calculated on the basis of the average nominal rate during the year and the inflation rate one year ahead. 
imply a real transfer of resources between lenders and borrowers. Debt servicing burdens will also increase when ex post real rates go up. If the change is large it could lead to serious difficulties for borrowers with potentially deflationary effects when borrowers belong to the more active sectors and have higher spending propensities than lenders. This could cause a significantly higher frequency of bankruptcies, with direct real economic consequences and adverse effects on the banking system, that could even result in a credit crunch. Such effects are usually ignored in well-behaved macroeconomic models

Another channel of deflation could materialise if borrowers experience unexpectedly high real ex post real interest which might affect their expectations concerning future real interest rates or make them more uncertain about their expectations. This could then lead to a higher degree of precaution among investors and consumers with adverse consequences for investment and consumption.

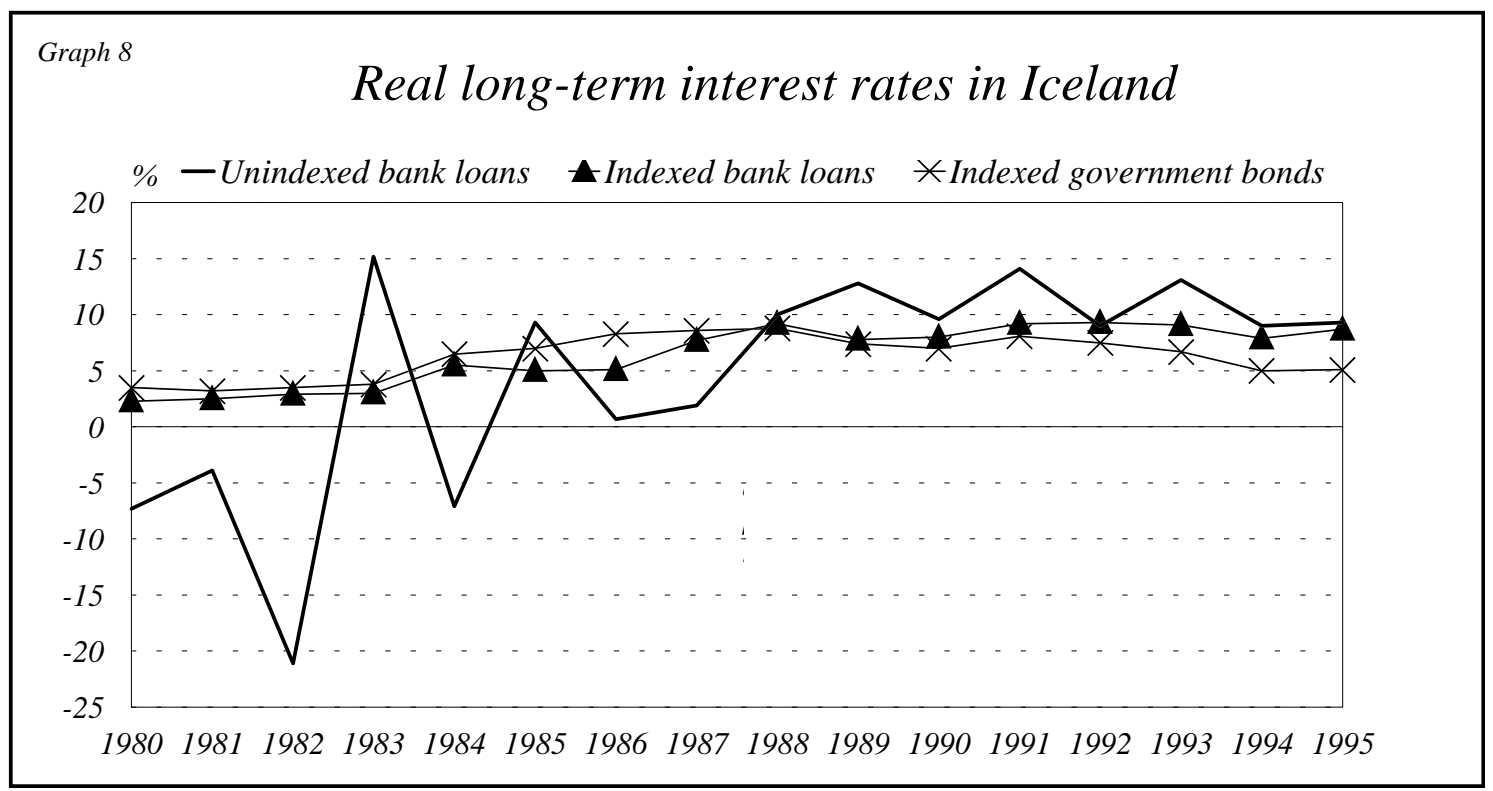

\section{The role of fiscal and monetary policies}

We have seen that exchange rate policy played an important role in both stages of the disinflation program. ${ }^{81}$ But what about fiscal policy and monetary policy apart from exchange rate policy? We will now consider both in turn.

\section{Fiscal policy}

The financial deficit of the general government amounted to less than $1 \%$ of GDP during the 1980s and gross debt was 30\% of GDP at the end of the decade. The deficit was higher during the 1990 s, or $31 / 2 \%$ of GDP during $1990-1995$, but below $2 \%$ in 1996 . At that time gross debt had increased to $56 \%$ of GDP. This is a relatively more favourable fiscal position than on average among OECD countries. However, from the standpoint of the general macroeconomic

81 A more theoretical discussion of exchange rate policies in Iceland may be found in Krugman (1991). 
balance in Iceland during the nineties, fiscal policy was probably not sufficiently tight, as witnessed by the relatively low national savings rate and the emerging current account deficit as the economy started to pick up. On the other hand, this relatively favourable position made it possible to use fiscal policy for cyclical stabilisation and to support wage moderation. This was especially important in the disinflation of the 1990s.

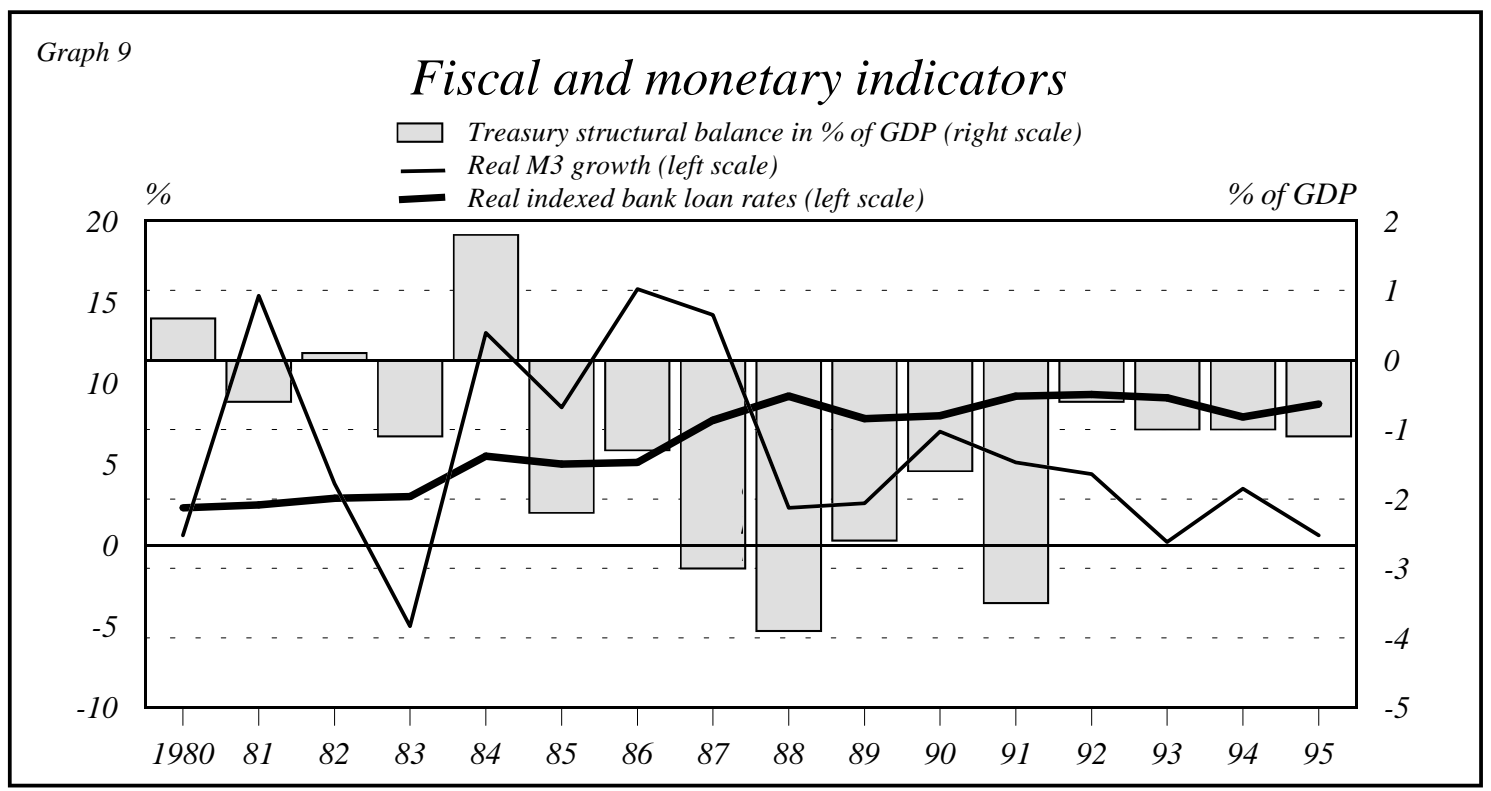

Fiscal tightening did not play any explicit role in the first stage of disinflation. The structural budget balance of the Treasury actually worsened significantly in 1983 but then improved sharply in 1984 (see graph 9). ${ }^{82}$ However, this had though as much to do with a long strike of public employees as with any deliberate fiscal tightening, and the structural deficit increased sharply again in 1985. In 1986, the deficit rose further as fiscal concessions were used to "buy" moderate wage settlements. The situation was somewhat different during the second stage of disinflation in the nineties. Fiscal policy was deliberately tightened in 1989 and 1990 as a part of the process of lowering the real exchange rate to a sustainable level at the same time as inflation was kept in check and then subsequently reduced. This shows up clearly in graph 9 . There where some slippages in 1991, to be reversed in 1992 and fiscal policy contributed to the wage settlement in May 1993 when zero wage increases over a 11/2 year period were "bought" with a significant reduction in VAT on food.

\section{Monetary policy}

Exchange rate stability played an important part in both stages of disinflation, as did the structural reforms that affected the long-term real interest rate. First came financial indexation in

82. Graph 9 gives the structural budget balance of the Treasury on a cash basis rather than the more traditional general government balance on an accrual basis. The reason is twofold. Firstly, the balance on an accrual basis includes in different years liabilities that have accrued over a period of years but are then charged as expenditure at discreet and accidental intervals. That obscures the estimates of the demand effects of general government finances in individual years. Secondly, the economic policy discussion was based on the Treasury balance on a cash basis. 
the early 1980s that turned the real interest rate positive. Then came the liberalisation of domestic interest rates after the middle of the 1980s which led to real rates on indexed bank loans in 1988 of over $9 \%$. This significantly helped to cool down the economy and thus created better conditions for disinflation. On the other hand, the targeting of monetary aggregates or the control of short-term liquidity or interest rates did not play any significant role in the disinflation process. Broad money (M3) actually grew more than nominal GDP every year from 1980 until 1995, as money demand was recovering from the experience of high inflation and negative real interest rates. Moreover, econometric studies have strongly indicated that prices caused money and not vice versa during this period. ${ }^{83}$ This result is consistent with the accommodating monetary policy. It is important in this respect that a money market did not develop in Iceland until 1992-93 and that an inter-bank market for foreign exchange only came into operation in May 1993. These and other structural reforms have meant that the role of monetary policy in keeping inflation low through short-term interest rates has greatly increased. ${ }^{84}$ In all cases, inflation is ultimately a monetary phenomena. A monetary expansion of some sort is a necessary corollary of inflation and a monetary restraint a corollary of disinflation. However, the channels through which this occurs can differ, depending on the specific circumstances and conditions. In Iceland, the exchange rate played the main role.

\section{Conclusions}

During the 1980s most countries have come to the conclusion that high inflation is both unsustainable and costly. However, very few started the process of disinflation from such a high level as Iceland. This makes the disinflation experience of Iceland quite unique among the industrial countries and from a national historic perspective as well. Even though Iceland's disinflation was not costless, it is also unique in the sense that the costs, in terms of lost output and higher unemployment, were relatively low.

The disinflation in Iceland has taken place in two stages. The first stage, starting in 1983, was in response to a crisis, as inflation had accelerated to over $80 \%$ and was threatening to go even higher. Like other countries, mostly in Latin America, in a similar situation the stabilisation measures adopted produced very quick results as the rate of inflation dropped to the $20-30 \%$ range within just one year. Moreover, led by private consumption and later by a pick-up in investment, output growth quickly recovered.

However, only few countries have managed to keep inflation stable in the 20-30\% range and because of other macroeconomic imbalances, partly due to an overheating economy, Iceland soon faced the need for further stabilisation. A second stage of disinflation was, therefore, launched in 1989-90 which eventually brought inflation down to 2-3\%. The second stage differed in several respects from the first one and involved a large-scale reorientation of policy pri-

83. For instance Gunnarsson (1996).

84. On the structural reforms affecting monetary policy during the nineties and its new role, see Gudmundsson and Kristinsson (1997). 
orities and strategies. Reflecting the earlier experience with high inflation but also influenced by the deregulation of financial markets and interest rates, a consensus had gradually been formed that the general public was best served by low and stable inflation. Moreover, it was increasingly realised that devaluations which are not supported by other macroeconomic policies and by the general economic conditions will mainly result in higher inflation. Consequently, a key element of the second stage was a reorientation of policies towards keeping inflation low and stable and away from the earlier devaluation bias and the high priority attached to full employment. Moreover, an important supporting element was a consensus-based and forward looking low wage settlement.

Unlike the first disinflation episode, the second was not costless. However, in this respect Iceland's experience is similar to that of other countries that have reduced inflation from the moderate range of $20-30 \%$ to the range of $2-3 \%$. In fact, when taking account of the shocks to which the Icelandic economy was exposed in the early 1990s, it might be argued that the costs were rather small and probably smaller than in other countries. Moreover, most of the benefits of lower inflation are still to come.

There are several features that have helped Iceland in reducing the costs of disinflation. One is the high degree of real wage flexibility and the willingness of workers to partly absorb negative shocks in lower real wages. Secondly, the use of incomes policies seems to have eased the adjustment to lower inflation, especially at the initial stage. Thirdly, widespread financial indexation has helped to stabilise ex post real interest rates even though inflation expectations were slow to adjust to actual inflation.

Despite these favourable elements, it appears that the rate of unemployment consistent with stable inflation (the NAIRU) has increased, possibly to around 4\%. However, several caveats should be mentioned in this respect. First, earlier rates of around $1 \%$ were probably neither sustainable nor consistent with stable inflation. Secondly, to the extent that the rise in the NAIRU is due to the fall in the investment/GDP ratio and the lower growth of the capital stock, it should not be attributed to the policy of disinflation. Finally, measures of the NAIRU are extremely uncertain, especially in countries, such as Iceland, that are exposed to large external shocks.

Exchange rate policy and incomes policy played the main roles during the disinflation process. Fiscal policy played more of a supportive role, especially during the second stage. The real interest rate shocks that accompanied financial indexation and the liberalisation of domestic interest rates cooled down the economy and created favourable conditions for disinflation. Monetary policy operating through short-term liquidity and interest rate channels has only recently become important in keeping inflation at check. 


\section{Bibliography}

Akerlof, G.A., W.T. Dickens and G.L. Perry (1996): "The Macroeconomics of Low Inflation", Brookings Papers on Economic Activity, pp. 1-60.

Andersen, P.S. (1992): "OECD Country Experiences with Disinflation", in A. Blundell-Wignall (ed.) Inflation, Disinflation and Monetary Policy, Proceedings of a Conference, Reserve Bank of Australia, pp. 104-81.

Andersen, P.S. (1997): "Macroeconomic Developments in the Nordic Countries", in Monetary Policy in the Nordic Countries after 1992, BIS Policy Discussion Papers, No.2.

Andersen, P.S. and D. Gruen (1995): "Macroeconomic Policies and Growth" in P.S. Andersen, J. Dwyer and D. Gruen (eds.) Productivity and Growth, Proceedings of a Conference, Reserve Bank of Australia, pp. 279-320.

Andrés, J. and I. Hernando (1997): "Inflation and Economic Growth: Some Evidence for the OECD Countries", in Monetary Policy and the Inflation Process, BIS Conference Papers, Volume IV, pp. 364-84.

Ball, L. (1993): "What Determines the Sacrifice Ratio?", NBER Working Paper, No. 4306.

Ball, L. and N.G. Mankiw (1992): "Relative-Price Changes as Aggregate Supply Shocks", NBER Working Paper, No. 4168.

Ball, L., N. Mankiw and D. Romer (1988): "New Keynesian Economics and the Output-inflation Trade-off", Brookings Papers on Economic Activity, pp. 1-66.

Barone, E. and R. S. Masera (1997): "Index-linked Bonds from an Academic, Market and Policy-making Standpoint", in M. de Cecco, M. L. Pecchi and G. Piga (eds.) Managing Public Debt: Index-linked Bonds in Theory and Practice, Edward Elgar Publ..

Blanchard, O. and J.F. Jimeno (1995): "Structural Unemployment: Spain versus Portugal", American Economic Review, May, pp. 212-17.

Bomfim, A., R. Tetlow, P. von zur Muehlen and J. Williams (1997): "Expectations, Learning and the Costs of Disinflation. Experiments using the FRB/US Model", in Monetary Policy and the Inflation Process, BIS Conference Papers, Volume IV, pp. 222-44.

Briault, C. (1995): "The Costs of inflation", Quarterly Bulletin, Bank of England, February, pp. 33-45.

Bruno, M. (1993): Crisis, Stabilisation and Economic Reform, Clarendon Press, Oxford.

Bruno, M. and W. Easterly, (1995): "Inflation Crisis and Long-run Growth", NBER Working Paper, No. 5209.

Burton, D. and Fischer, S. (1997): "Ending Moderate Inflations", preliminary draft.

Calvo, G.A. and C.A. Végh (1994): "Inflation Stabilisation and Nominal Anchors", Contemporary Economic Policy, pp. 35-45.

Chadha, B., P. Masson and G. Meredith (1992): "Models of Inflation and the Costs of Disinflation", IMF Staff Papers, pp. 395-431.

Cukierman, A. (1992): Central Bank Strategy, Credibility and Independence, MIT-Press, pp. 2795.

Debelle, G. (1996): "The Ends of Three Small Inflations: Australia, New Zealand and Canada", Canadian Public Policy, pp. 56-78.

De Abreu Lourenco, R. and D. Gruen (1995): "Price Stickiness and Inflation", Research Discussion Paper, No. 9502, Reserve Bank of Australia. 
Detragiache, E. and A.J. Harmann (1997): "Exchange-rate-based Stabilisation in Western Europe: Greece, Ireland, Italy and Portugal", IMF Working Paper, No.97/75.

Dornbusch, R. (1986): "Money, Interest Rates and Stabilisation", Review of Economic Conditions in Italy, No. 3, pp. 173-210.

Dornbusch, R. (1989): "Credibility, Debt and Unemployment: Ireland's failed Stabilisation", Economic Policy, pp. 173-210.

Dornbusch, R. and S. Fischer (1991): "Moderate Inflation", NBER Working Paper, No. 3896.

Driffill, J., G.E. Mizon and A. Ulph (1990): "Costs of Inflation", in B. M. Friedman and F. Hahn (eds.), Handbook of Monetary Economics, Vol. II, Ch. 19.

Edey, M. (1994): "Costs and Benefits of Moving from Low Inflation to Price Stability", OECD Economic Studies, Winter, pp. 109-130.

Easterly, W. (1996): "When is Stabilisation Expansionary? Evidence From High Inflation", Economic Policy, No. 21, pp. 67-107.

Fischer, S. (1996): "Why are Central Banks Pursuing Long-run Price Stability?", in Achieving Price Stability, Symposium sponsored by the Federal Reserve Bank of Kansas City, pp. 734.

Gagnon, J.E. (1996): "Long Memory in Inflation Expectations: Evidence from International Financial Markets", International Finance Discussion Papers, No. 538, Board of Governors of the Federal Reserve System.

Gordon, R.J. (1982): "Why Stopping Inflation may be Costly: Evidence from Fourteen Historical Episodes" in R. Hall (ed.) Inflation: Causes and Effects, Chicago University Press, pp. 9-40.

Gray, J.A. (1978): "On Indexation and Contract Length", Journal of Political Economy, pp. 118.

Gros, D. (1993): "Seigniorage and EMU: The Fiscal Implications of Price Stability and Financial Market Integration", European Journal of Political Economy, pp. 581-601.

Gudmundsson, B. and G. Zoega (1996): "Unemployment in Iceland: Is there a Natural Rate?", National Economic Institute, Iceland.

Gudmundsson, M. (1994): "In Search of Stability: Iceland's Exchange Rate and Monetary Policies", Economic and Financial Review, pp. 123-52.

Gudmundsson, M. and Y. Ö. Kristinsson (1997): "Monetary Policy in Iceland during the 1990s" in Monetary Policy in the Nordic Countries after 1992, BIS Policy Discussion Papers, No.2.

Gunnarsson, T. G. (1996): "Demand for Money in Iceland", Fjármálatidindi, (in Icelandic).

Hansson, T. (1997): "Seigniorage, Inflation and Government Finances in Iceland", Central Bank of Iceland, Economics Department, Mimeo.

Herbertsson, T.T. and G. Magnusson (1995): "Accounting for Growth in the Five Nordic Countries, 1971-92", Working Papers, No. 95:10, Institute of Economic Studies.

Hess, G.D. and C.S. Morris (1996): "The Long-run Costs of Moderate Inflation", Quarterly Review, Federal Reserve Bank of Kansas City, 2nd Quarter, pp. 71-88.

Hutchison, M. and C. Walsh (1996): "Central Bank Institutional Design and the Output Costs of Disinflation: Did the 1989 New Zealand Reserve Bank Act affect the Inflation-output Trade-off?", Working Paper, No. 96/6, Reserve Bank of New Zealand.

IMF (1996): World Economic Outlook, October. 
Judson, R. and A. Orphanides (1996): "Inflation, Volatility and Growth", Finance and Economics Discussion Series, No. 96-14, Board of Governors of the Federal Reserve System.

Kaminsky, G. L. and L. Leiderman (1993): "High Real Interest Rates in the Aftermath of Disinflation: Actual or Expected?", Finance and Economics Discussion Series, No. 93-33, Board of Governors of the Federal Reserve System, Washington, D.C.

Khamis, M. (1996): "Credit and Exchange-Rate-Based Stabilisation", IMF Working Paper, No. $96 / 51$.

Krugman, P. (1991): "Iceland's Exchange Rate Regime", Memo, May.

Kun, J. (1996) "Seigniorage and Burdens of Government Debt", National Bank of Hungary Workshop Studies, No. 3.

Leiderman, L. (1993): Inflation and Disinflation: The Israeli Experiment, The University of Chicago Press, pp. 9-65.

Levine, R. and D. Remelt (1992): "A Sensitivity Analysis of Cross-Country Growth Regressions", American Economic Review, pp. 942-63.

Lucas, R.E. (1973): "Some International Evidence on Output-Inflation Trade-offs", American Economic Review, pp. 526-34.

OECD (1982-97): Economic Surveys of Iceland, OECD, Paris.

Posen, A. (1995): "Central Bank Independence and Disinflationary Credibility: The Missing Link", Staff Reports, No. 1, Federal Reserve Bank of New York.

Price, R. (1997): "The Rationale and Design of Inflation-indexed Bonds", IMF Working Paper, No. 97/12.

Sarel, M. (1996): "Nonlinear Effects of Inflation on Economic Growth", IMF Staff Papers, pp. 199-215.

Sargent, T. J. (1982): "The Ends of Four Big Inflations" in R. Hall (ed.) Inflation: Causes and Effects, Chicago University Press, pp. 41-99.

Tanzi, V. (1977): "Inflation, Lags in Collection, and the Real Value of Tax Revenue", IMF Staff Papers, pp. 154-67.

Taylor, J. (1983): "Union Wage Settlements during a Disinflation", American Economic Review, pp. 981-93.

Végh, C.A. (1992): "Stopping High Inflation", IMF Staff Papers, pp. 626-695.

Walsh, B. (1996): "Stabilisation and Adjustment in a Small Open Economy: Ireland, 1979-95", Oxford Review of Economic Policy, pp. 74-86.

Yates, A. and B. Chappel, (1996): "What Determines the Short-run Output-Inflation Trade-off?", Working Paper Series, No. 53, Bank of England. 


\section{Annex A}

\section{A model of inflation in Iceland}

In this annex we present a model of price and wage inflation in Iceland during the period 1970-1995. We took the extensive research that has been done over the years at the Central Bank of Iceland on price and wage formation as our starting point ${ }^{1}$. The price equation that has emerged from this research is basically of the mark-up on cost type, where price inflation depends on current and lagged changes and levels of wages and import prices. The most important variables in the wage equation have been price inflation and the share of wages in national income. For theoretical reasons we only considered the unit labour cost variable instead of estimating separately the effects of wages and productivity in the price equation presented below ${ }^{2}$. We then tested the model for various specifications and missing variables and ended up with the following model (omitting dummy variables and error terms):

$$
\begin{aligned}
& \Delta \mathrm{p}=\beta_{1} \Delta \mathrm{ulc}+\beta_{2} \Delta \mathrm{ulc}_{-1}+\beta_{3} \Delta \mathrm{pm}+\beta_{4} \Delta \mathrm{pm}_{-1}+\beta_{5} \Delta \mathrm{p}_{-1} \\
& \Delta \mathrm{w}=\alpha+\beta_{6} \Delta \mathrm{p}+\beta_{7}\left(\mathrm{w}-\left(\mathrm{gnp}_{-1}\right)\right)_{-1}+\beta_{8} \mathrm{u}_{-1}+\beta_{9} \Delta(\mathrm{m}-\mathrm{p})_{-1}+\beta_{10} \Delta \mathrm{w}_{-2}
\end{aligned}
$$

Variables:

$\mathrm{p}=$ consumer price index

ulc $=$ unit labour cost

$\mathrm{pm}=$ import prices in terms of domestic currency

$\mathrm{w}=$ wages (hourly earnings of skilled and unskilled workers)

gnp $=$ nominal gross national product

$1=$ labour (number of man-years)

$\mathrm{u}=$ rate of unemployment

$\mathrm{m}=\mathrm{M} 3$

All variables are in logarithms and $\Delta$ stands for first difference.

We estimated the model on biannual data from 1970-1995 using two stage least squares (instrumental variables) estimator ${ }^{3}$. Table 1 shows the estimated price equation. The model performs rather well but fails the functional form test. It includes a moving average error term $\left(e_{-1}\right)$ that is difficult to get rid of by any acceptable respecification of the model. Error correction terms involving unit labour costs and import prices were either insignificant or had the wrong signs. The model was tested for several missing variables, including the output gap, money supply and

1. See Gudmundsson, G. (1984) and Gudmundsson G. (1990).

2. Productivity is insignificant when entered separately into the price equation and the equation is no longer homogeneous. Productivity here is measured by GDP per employee.

3. Biannual data were used to avoid non-normality problems with the error term in equations based on quarterly data. This problem is probably caused by the effects of centralised bargaining that will make wage increases occur in big steps at discreet intervals. 
Table 1. Price equation

\begin{tabular}{|l|rr|}
\hline Explanatory variables: & Parameter & t-value \\
\hline$\Delta \mathrm{ulc}$ & 0.34 & 5.72 \\
$\Delta \mathrm{ulc}-1$ & 0.16 & 2.67 \\
$\Delta \mathrm{pm}$ & 0.25 & 6.91 \\
$\Delta \mathrm{pm}_{-1}$ & 0.09 & 1.73 \\
$\Delta \mathrm{p}_{-1}$ & 0.18 & 2.08 \\
$\varepsilon_{-1}$ & -0.52 & 3.69 \\
Estimation period & $1995: 2$ & \\
Observations & 49 & \\
$\overline{\mathrm{R}}^{2}$ & 0.957 & \\
Standard error x 100 & 1.70 & $\mathrm{p}-\mathrm{value}$ \\
Serial correlation (Q - 12) & 13.36 & 0.270 \\
Normal distribution (JB) & 0.611 & 0.737 \\
Heteroscedasticity (F-arch) & 0.185 & 0.832 \\
Heteroscedasticity (White) & 1.336 & 0.247 \\
Functional form (RESET) & 9.53 & 0.000 \\
Structural break (1985:1) & 1.828 & 0.120 \\
Chow forecast test (1991:1) & 0.517 & 0.866 \\
Homogeneity & 3.743 & 0.060 \\
\hline
\end{tabular}

credit. None of these were significant. The functional form test and the moving average term indicate that we have not found the best model and that there might also be problems with the biannual data. But the model is good enough to give us the instruments for the wage equation that we are mainly interested in.

Table 2 gives the estimated wage equation, where we have added a dummy variable (D1) for the period of wage indexation, taking the value 1 until the first half of 1983 and zero thereafter. It indicates that indexation boosted wage inflation by an average of $7 \%$ per annum during this period, controlling for other variables. The model below passes all the statistical tests listed in the table.

Table 2. Wage equation 1

\begin{tabular}{|l|rr|}
\hline Explanatory variables: & Parameter & t-value \\
\hline constant & 2.120 & 3.42 \\
$\Delta \mathrm{p}$ & 0.585 & 5.27 \\
$(\mathrm{w}-(\mathrm{gnp}-\mathrm{l}))_{-1}$ & -0.310 & -3.37 \\
$\mathrm{u}_{-1}$ & -0.054 & -4.52 \\
$\Delta(\mathrm{m}-\mathrm{p})_{-1}$ & 0.346 & 2.47 \\
$\Delta \mathrm{w}_{-2}$ & -0.243 & -2.52 \\
$\mathrm{D} 1$ & 0.034 & 2.39 \\
& & \\
Estimation period & 0.860 & \\
Observations & 3.01 & $\mathrm{p}-\mathrm{value}$ \\
$\mathrm{R}^{2}$ & 10.01 & 0.614 \\
Standard error x 100 & 1.74 & 0.419 \\
Serial correlation (Q - 12) & 0.571 & 0.569 \\
Normal distribution (JB) & 0.910 & 0.540 \\
Heteroscedasticity (F-arch) & 0.068 & 0.935 \\
Heteroscedasticity (White) & 0.982 & 0.478 \\
Functional form (RESET) & & \\
Chow forecast test (1991:1) & & \\
\hline
\end{tabular}


Table 3. Wage equation 2

\begin{tabular}{|l|rr|}
\hline Explanatory variables: & Parameter & t-value \\
\hline constant & 1.755 & 2.79 \\
$\Delta \mathrm{p}$ & 0.661 & 5.90 \\
$\left(\mathrm{w}-(\text { gnp-1) })_{-1}\right.$ & -0.253 & 2.72 \\
$\mathrm{u}_{-1}$ & -0.063 & -5.38 \\
$\Delta(\mathrm{m}-\mathrm{p})_{-1}$ & 0.332 & 2.27 \\
$\Delta \mathrm{w}_{-2}$ & -0.301 & -3.07 \\
Estimation period & & \\
Observations & $4971: 2-1995: 2$ & \\
$\overline{\mathrm{R}}^{2}$ & 0.847 & \\
Standard error x 100 & 3.16 & $\mathrm{p}-\mathrm{value}$ \\
Serial correlation $(\mathrm{Q}-12)$ & 7.28 & 0.839 \\
Normal distribution $(\mathrm{JB})$ & 1.07 & 0.587 \\
Heteroscedasticity (F-arch) & 0.96 & 0.391 \\
Heteroscedasticity (White) & 0.75 & 0.676 \\
Functional form (RESET) & 0.77 & 0.386 \\
Structural break (1985:1) & 1.50 & 0.205 \\
Chow forecast test (1991:1) & 1.15 & 0.355 \\
\hline
\end{tabular}

If the dummy variable for indexation is excluded we get the model in table 3 . The standard error is somewhat higher but, overall, the model performs well and passes all the standard tests.

The recursive estimates for the error correction term (the wage share), unemployment and the growth of the real money supply are shown below. It appears that the speed of adjustment of wages to changes in national income was somewhat reduced after the middle of the 80 s.
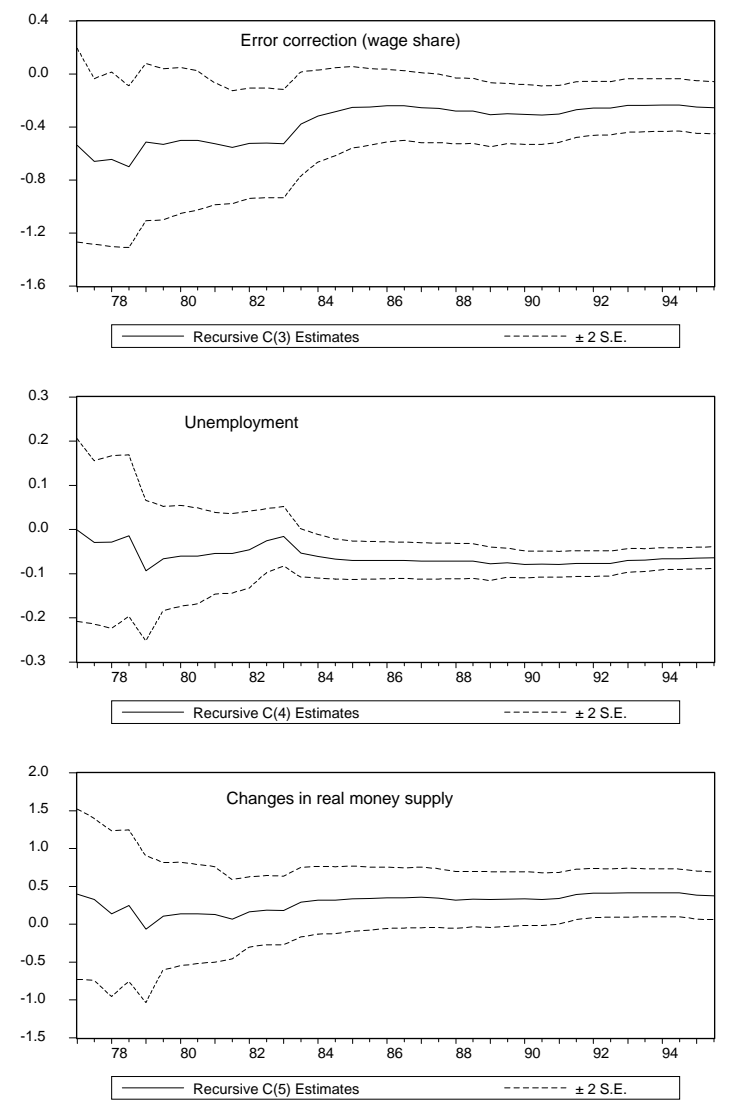
Secondly, the unemployment term only becomes significant after the middle of the 80 s and the real money supply still later. This indicates that certain changes occurred during this period that may have contributed to the subsequent disinflation process during the $90 \mathrm{~s}$. It is, though, not completely clear what the role of the real money supply term is.

\section{References:}

Gudmundsson, G. (1984): "Inflation in Iceland from 1964 to 1981", A paper presented at the European Meeting of the Econometric Society in Madrid, September 1984, Mimeo.

Gudmundsson, G. (1990): "A statistical analysis of inflation in Iceland during 1962-1989", (Published in Icelandic), Fjármálatíðindi, 1, 1990. 


\section{Annex B}

Table 1. Main Developments during 1st Stage of Disinflation In percentages or percentage changes

\begin{tabular}{|c|c|c|c|c|c|c|c|c|}
\hline Items & 1980 & 1981 & 1982 & 1983 & 1984 & 1985 & 1986 & 1987 \\
\hline GDP growth & 5.6 & 4.3 & 2.2 & -2.2 & 4.1 & 3.3 & 6.3 & 8.5 \\
\hline Inflation 1 & 58.5 & 50.9 & 51.0 & 84.3 & 29.2 & 32.4 & 21.3 & 18.8 \\
\hline Wages $^{2}$ & 52.7 & 54.5 & 52.9 & 55.4 & 27.7 & 42.2 & 32.2 & 42.5 \\
\hline Real wage gap ${ }^{3}$ & 0.0 & 4.1 & 4.3 & -5.2 & -6.0 & 2.2 & 4.4 & 21.4 \\
\hline Real money growth ${ }^{4}$ & 0.6 & 15.4 & 3.8 & -5.0 & 13.1 & 8.5 & 15.8 & 14.2 \\
\hline Nominal interest rate 5 & 39.9 & 45.1 & 45.4 & 48.8 & 23.0 & 32.5 & 19.6 & 27.9 \\
\hline Real interest rate 6 & -8.3 & -1.7 & -9.4 & -14.2 & 3.4 & -2.3 & 4.3 & 4.7 \\
\hline Indexed interest rate 7 & 3.5 & 3.2 & 3.5 & 3.8 & 6.5 & 7.0 & 8.3 & 8.6 \\
\hline Fiscal balance $^{8}$ & 1.3 & 1.3 & 1.7 & -2.0 & 2.2 & -1.7 & -4.1 & -0.9 \\
\hline Consumption & 3.4 & 6.2 & 4.9 & -5.6 & 3.7 & 4.2 & 6.9 & 16.2 \\
\hline Private fixed investment & 13.3 & -0.8 & -0.4 & -13.2 & 10.8 & 0.1 & -1.2 & 20.0 \\
\hline Nom. eff. exch. rate ${ }^{9}$ & -27.3 & -25.3 & -36.3 & -45.5 & -14.0 & -21.8 & -13.1 & -3.6 \\
\hline Real eff. exch. rate ${ }^{10}$ & 0.0 & 4.3 & -8.2 & -5.8 & 4.9 & -1.6 & 2.0 & 9.5 \\
\hline Exports of goods \& serv. & 2.7 & 3.2 & -8.9 & 11.0 & 2.4 & 11.1 & 5.9 & 3.3 \\
\hline Real export revenue ${ }^{11}$ & -1.9 & 2.7 & -9.7 & 9.6 & 3.1 & 10.0 & 11.7 & 7.7 \\
\hline Terms of trade & -2.8 & -0.5 & -0.8 & -1.3 & 0.6 & -0.9 & 5.4 & 4.3 \\
\hline Current account ${ }^{12}$ & -2.3 & -4.3 & -8.1 & -2.1 & -4.7 & -4.0 & 0.5 & -3.5 \\
\hline GDP gap ${ }^{13}$ & 3.1 & 3.3 & 1.6 & -3.9 & -3.2 & -3.0 & 0.3 & 6.1 \\
\hline Employment growth & 3.4 & 5.2 & 2.5 & 0.9 & 1.4 & 3.6 & 3.1 & 5.8 \\
\hline Unemployment rate & 0.3 & 0.4 & 0.7 & 1.0 & 1.3 & 0.9 & 0.6 & 0.4 \\
\hline
\end{tabular}

Table 2. Main Developments during 2nd Stage of Disinflation

In percentages or percentage changes

\begin{tabular}{|c|c|c|c|c|c|c|c|c|}
\hline Items & 1988 & 1989 & 1990 & 1991 & 1992 & 1993 & 1994 & 1995 \\
\hline GDP growth & -0.1 & 0.3 & 1.2 & 1.2 & -3.3 & 0.9 & 3.5 & 1.2 \\
\hline Inflation ${ }^{1}$ & 25.5 & 21.1 & 14.8 & 6.8 & 3.8 & 4.1 & 1.5 & 1.7 \\
\hline Wages $^{2}$ & 22.4 & 11.0 & 12.4 & 9.4 & 2.3 & 0.2 & 2.2 & 5.2 \\
\hline Real wage gap ${ }^{3}$ & 17.5 & 7.0 & 0.8 & 1.1 & 1.8 & -2.2 & -4.3 & -3.8 \\
\hline Real money growth 4 & 2.3 & 2.6 & 7.0 & 5.1 & 4.4 & 0.2 & 3.5 & 0.6 \\
\hline Nominal interest rate 5 & 33.2 & 29.5 & 17.1 & 18.4 & 13.5 & 14.8 & 10.9 & 11.8 \\
\hline Real interest rate ${ }^{6}$ & 11.8 & 6.5 & 9.3 & 10 & 11.8 & 11.5 & 9.5 & 10.1 \\
\hline Indexed interest rate 7 & 8.8 & 7.4 & 7.0 & 8.1 & 7.5 & 6.7 & 5.0 & 5.1 \\
\hline Fiscal balance $^{8}$ & -2.0 & -4.5 & -3.3 & -2.9 & -2.8 & -4.5 & -4.7 & -3.0 \\
\hline Consumption & -3.8 & -4.2 & 0.5 & 4.1 & -4.5 & -4.4 & 1.8 & 4.6 \\
\hline Private fixed investment & -3.4 & -9.1 & 3.9 & 0.9 & -13.2 & -18.2 & 0.3 & 0.5 \\
\hline Nom. eff. exch. rate ${ }^{9}$ & -12.5 & -20.5 & -10.2 & 0.0 & -0.5 & -7.7 & -4.9 & 0.8 \\
\hline Real eff. exch. rate 10 & 5.2 & -8.1 & -3.2 & 2.6 & 0.0 & -5.4 & -5.5 & 0.1 \\
\hline Exports of goods \& serv. & -3.6 & 2.9 & 0.0 & -5.8 & -1.7 & 6.6 & 9.9 & -2.3 \\
\hline Real export revenue ${ }^{11}$ & -4.3 & -1.1 & -2.0 & -2.6 & -4.4 & 1.3 & 9.8 & -1.2 \\
\hline Terms of trade & -0.8 & -3.9 & -2.0 & 3.4 & -2.7 & -5.0 & 0.0 & 1.1 \\
\hline Current account ${ }^{12}$ & -3.6 & -1.5 & -2.2 & -4.7 & -3.1 & 0.1 & 1.9 & 0.8 \\
\hline GDP gap 13 & 3.7 & 1.9 & 1.4 & 1.0 & -3.8 & -4.3 & -2.4 & -2.8 \\
\hline Employment growth & -3.0 & -1.4 & -0.9 & -0.1 & -1.4 & -0.8 & 0.5 & 1.5 \\
\hline Unemployment rate & 0.6 & 1.7 & 1.8 & 1.5 & 3.1 & 4.4 & 5.0 & 4.4 \\
\hline
\end{tabular}

Notes: 1. Consumer price index; 2. Compensation per employee; 3. Deviation of real labour costs (compensation per employee divided by GDP deflator) from labour productivity (GDP/total employment), $1980=0 ; 4$. M3 deflated by consumer prices; 5. Unindexed bank loans; 6. Unindexed bank loans less rate of inflation (December-December); 7. Real rate on indexed long-term government bonds; 8 . General government net lending in per cent of GDP; 9. Percentage change in effective exchange rate (rise indicates appreciation); 10. Relative CPI in common currency; 11. Exports of goods and services deflated by import prices; 12 . As a percentage of GDP; 13. Percentage deviation of actual from potential GDP (proxied by a HP-trend). 
Table 3. Changes in Domestic Demand Deflators by Contributing Factor In percentages and percentage point contributions

\begin{tabular}{|l|r|r|r|}
\hline Countries/Items & $1980-85$ & $1986-1990$ & $1991-95$ \\
\hline Iceland & & & \\
dPDD & 46.5 & 20.5 & 3.9 \\
dULC & 21.0 & 11.5 & 1.9 \\
dPROF & 17.7 & 6.0 & 1.2 \\
dTIND & 7.0 & 3.0 & 0.1 \\
d (PM -PX) & 0.3 & -0.2 & 0.3 \\
Res. & 0.5 & 0.2 & 0.4 \\
\hline Ireland & & & \\
dPDD & 10.3 & 3.6 & 3.0 \\
dULC & 4.4 & 1.1 & 0.6 \\
dPROF & 5.1 & 1.8 & 0.9 \\
dTIND & 1.5 & 0.3 & 0.3 \\
d (PM - PX) & -0.6 & 0.1 & 0.7 \\
Res. & -0.1 & 0.3 & 0.5 \\
\hline New Zealand & & & \\
dPDD & 12.3 & 7.3 & 1.8 \\
dULC & 4.2 & 3.6 & 0.4 \\
dPROF & 6.0 & 3.3 & 1.6 \\
dTIND & 1.4 & 1.9 & 0.0 \\
d (PM - PX) & 0.1 & -1.3 & -0.1 \\
Res. & 0.6 & -0.2 & -0.1 \\
\hline Portugal & & & \\
dPDD & 21.8 & 11.6 & 7.0 \\
dULC & 10.0 & 6.3 & 4.2 \\
dPROF & 9.0 & 4.8 & 3.0 \\
dTIND & 3.6 & 2.4 & 0.7 \\
d (PM - PX) & 0.0 & -0.8 & -0.4 \\
Res. & -0.8 & -1.1 & -0.5 \\
\hline
\end{tabular}

Note: The contributions are calculated from national accounts data, using the equation: $\mathrm{dPDD}=\mathrm{a} \mathrm{dULCC}+\mathrm{b}$ $\mathrm{dPROF}$ c dTIND + e d (PM - PX) + Res., with dPDD = domestic demand deflator, dULC = compensation per unit of output, $\mathrm{dPROF}=$ gross profits per unit of output, $\mathrm{dTIND}=$ indirect taxes less subsidies per unit of output, $\mathrm{d}(\mathrm{PM}-\mathrm{PX})=$ import deflator relative to export deflator, Res. = residual and a,b,c and $\mathrm{e}=$ shares of respective components in GDP (1985). 


\section{Annex C}

Countries with over $30 \%$ annual inflation during three years or more

\begin{tabular}{|c|c|c|c|c|}
\hline Regional grouping & Inflation period & Average inflation & Inflation in $1996^{*}$ & IMF data \\
\hline \multicolumn{5}{|l|}{ Industrial Countries } \\
\hline Iceland & $1974-1983$ & $49.0 \%$ & $2.3 \%$ & $1950-1996$ \\
\hline Turkey & $1978-1996$ & $60.7 \%$ & $80.4 \%$ & $1954-1996$ \\
\hline \multicolumn{5}{|l|}{ Western Hemisphere } \\
\hline \multirow[t]{2}{*}{ Argentina } & $1971-1973$ & $51.5 \%$ & & \\
\hline & $1975-1991$ & $545.9 \%$ & $0.2 \%$ & $1949-1996$ \\
\hline \multirow[t]{2}{*}{ Bolivia } & $1953-1957$ & $119.8 \%$ & & \\
\hline & $1980-1986$ & $1969.4 \%$ & $10.2 \%(1995)$ & $1949-1995$ \\
\hline \multirow[t]{2}{*}{ Brazil } & $1959-1967$ & $50.4 \%$ & & \\
\hline & $1976-1995$ & $633.1 \%$ & $18.2 \%$ & $1958-1996$ \\
\hline \multirow[t]{2}{*}{ Chile } & $1954-1956$ & $24.1 \%$ & & \\
\hline & $1972-1980$ & $192.0 \%$ & $7.4 \%$ & $1950-1996$ \\
\hline Costa Rica & $1981-1983$ & $53.3 \%$ & $17.5 \%$ & $1951-1996$ \\
\hline Dominican Republic & $1988-1991$ & $50.8 \%$ & $12.5 \%(1995)$ & $1949-1995$ \\
\hline Ecuador & $1988-1993$ & $55.1 \%$ & $24.4 \%$ & $1952-1996$ \\
\hline Mexico & $1982-1988$ & $88.0 \%$ & $34.7 \%$ & $1949-1996$ \\
\hline Nicaragua & $1983-1991$ & $3031.7 \%$ & $11.6 \%$ & $1973-1996$ \\
\hline Paraguay & $1950-1953$ & $73.6 \%$ & $9.8 \%$ & $1949-1996$ \\
\hline Peru & $1976-1993$ & $723.5 \%$ & $11.5 \%$ & $1949-1996$ \\
\hline \multirow[t]{3}{*}{ Uruguay } & $1964-1968$ & $77.4 \%$ & & \\
\hline & $1972-1980$ & $68.4 \%$ & & \\
\hline & $1983-1995$ & $68.0 \%$ & $28.3 \%$ & $1949-1996$ \\
\hline Venezuela & $1989-1996$ & $56.2 \%$ & $99.9 \%$ & $1949-1996$ \\
\hline Suriname & $1992-1995$ & $197.8 \%$ & $-0.7 \%$ & $1955-1996$ \\
\hline \multicolumn{5}{|l|}{ Middle East } \\
\hline Israel & $1974-1986$ & $116.5 \%$ & $11.3 \%$ & $1949-1996$ \\
\hline Lebanon & $1985-1992$ & $125.6 \%$ & N.A. & $1967-1994$ \\
\hline Syrian Arab Rep. & $1986-1988$ & $43.4 \%$ & $8.3 \%$ & $1949-1996$ \\
\hline \multicolumn{5}{|l|}{ Asia } \\
\hline Afghanistan & $1989-1991$ & $57.9 \%$ & N.A & $1980-1991$ \\
\hline Bangladesh & $1972-1974$ & $48.2 \%$ & $2.7 \%$ & $1955-1996$ \\
\hline \multirow[t]{2}{*}{ Indonesia } & $1958-1960$ & $40.4 \%$ & & \\
\hline & $1962-1968$ & $294.9 \%$ & $7.9 \%$ & $1958-1996$ \\
\hline \multicolumn{5}{|l|}{ Africa } \\
\hline \multirow[t]{2}{*}{ Zaire } & $1976-1983$ & $60.7 \%$ & & \\
\hline & $1986-1996$ & $3056.7 \%$ & $658.8 \%$ & $1964-1996$ \\
\hline Ghana & $1976-1981$ & $77.8 \%$ & $34.1 \%$ & $1965-1996$ \\
\hline Guinea-Bissau & $1988-1993$ & $58.2 \%$ & $45.4 \%(1995)$ & $1988-1995$ \\
\hline Mozambique & $1987-1995$ & $51.8 \%$ & $54.4 \%(1995)$ & $1987-1995$ \\
\hline Nigeria & $1992-1995$ & $57.9 \%$ & $29.3 \%$ & $1954-1996$ \\
\hline Sierra Leone & $1983-1992$ & $84.5 \%$ & $23.2 \%$ & $1957-1996$ \\
\hline \multirow[t]{2}{*}{ Sudan } & $1983-1985$ & $36.7 \%$ & & \\
\hline & $1988-1993$ & $89.9 \%$ & N.A. & $1952-1993$ \\
\hline Tanzania & $1984-1986$ & $34.0 \%$ & $21.0 \%$ & $1966-1996$ \\
\hline Uganda & $1984-1990$ & $121.7 \%$ & $7.3 \%$ & $1981-1996$ \\
\hline Zambia & $1986-1996$ & $87.6 \%$ & $43.1 \%$ & $1986-1996$ \\
\hline \multicolumn{5}{|l|}{ Other Countries (n.i.e.) } \\
\hline Belarus & $1994-1996$ & $994.4 \%$ & $52.7 \%$ & $1994-1996$ \\
\hline Kazakstan & $1994-1996$ & $697.3 \%$ & $39.2 \%$ & $1994-1996$ \\
\hline Russia & $1993-1996$ & $356.7 \%$ & $47.6 \%$ & $1993-1996$ \\
\hline Ukraine & $1993-1995$ & $2034.3 \%$ & $376.8 \%$ (1995) & $1993-1995$ \\
\hline Latvia & $1992-1994$ & $129.3 \%$ & $17.6 \%$ & $1992-1996$ \\
\hline Lithuania & $1993-1995$ & $174.0 \%$ & $24.6 \%(1995)$ & $1993-1995$ \\
\hline Croatia & $1988-1994$ & $619.9 \%$ & $4.3 \%$ & $1987-1996$ \\
\hline Poland & $1988-1994$ & $139.2 \%$ & $21.0 \%$ & $1971-1996$ \\
\hline Romania & $1991-1994$ & $208.4 \%$ & $32.2 \%(1995)$ & $1971-1995$ \\
\hline
\end{tabular}

* Countries with inflation lower than 3\% p.a. in 1996 are highlighted 


\section{Annex D}

\section{Inflation expectations}

In this annex we analyse, more formally than in the main text, the data on inflation expectations, which are based on sample surveys that were taken 2-4 times a year during the period 1984-1993. We first make a simple test of the rationality of expectations. Formally we define inflation expectations to be rational if

$$
\pi_{t}=\pi_{t}^{e}+\varepsilon_{t}
$$

where $\pi_{t}$ stands for inflation at time $t, \pi_{t}^{e}=E\left(\pi_{t} \mid H_{t}\right)$ is expected inflation at time $t$ given the information set $H_{t}$. $\varepsilon_{t}$ is the forecast error that is independent of the information set, $E\left(\varepsilon_{t} \mid H_{t}\right)=$ 0 . In order to test the for rational expectations we can simply estimate the following model with OLS and do the hypothesis test in (2):

$$
\begin{aligned}
\pi_{t}=\alpha+\beta \pi_{t}^{e}+\varepsilon_{t} \\
H_{0}: \alpha=0, \beta=1
\end{aligned}
$$

The results are shown in (3):

$$
\pi_{t=-}-0.944+0.799 \pi_{t}^{e}
$$

$$
\begin{array}{lll}
H_{0}: \alpha=0 & F(1,32)=0.26 & p=0.62 \\
H_{0}: \beta=1 & F(1,32)=5.12 & p=0.03 \\
H_{0}: \alpha=0, \beta=1 & F(2,32)=5.40 & p=0.01
\end{array}
$$

$$
T=34, R^{2}=0.60, S E=6.36, D W=0.85
$$

where figures in brackets give Newey and West standard errors that are corrected for heteroscedasticity and autocorrelation in the error term. The hypothesis of rational expectations, as formulated here, is rejected by the data, as the coefficient on the expectations term is significantly different from unity.

We next test the data for adaptive expectations, as defined in (4):

$$
\pi_{t}^{e}=\theta \pi_{t-1}+(1-\theta) \pi_{t-1}^{e} ; \quad 0<\theta<1
$$

Inflation expectations in every period are a weighted average of the actual and expected inflation rates last period. If we solve (4) and rearrange we get:

$$
\pi_{t}^{e}=\theta \sum_{i=1}^{\infty}(1-\theta)^{i} \pi_{t-i}
$$

where inflation expectations only depend on lagged values of actual inflation. Substituting (5) into (2), gives:

$$
\pi_{t}=\alpha+\sum_{i=1}^{\infty} \gamma_{i} \pi_{t-i}+\varepsilon_{t}
$$

where $\gamma_{i}=\beta \theta(1-\theta)^{i}$. The estimated form of (6) is given in (7): 


$$
\begin{aligned}
& \pi_{t}=-0.855+0.933 \pi_{t-1}+0.261 \pi_{t-2}-0.438 \pi_{t-3}-0.190 \pi_{t-4}+0.422 \pi_{t-5} \\
& \begin{array}{lllll}
(0.64) & (0.27) & (0.36) & (0.17) & (0.25)
\end{array} \\
& T=34, R^{2}=0.92, S E=2.79, D W=1.81
\end{aligned}
$$

These estimates are consistent with the hypothesis of adaptive expectations. Another way to test this is to estimate (4) directly, that gives us (8) if we add a constant:

$$
\pi_{t}^{e}=\alpha+\delta \pi_{t-1}+\phi \pi_{t-1}^{e}+v_{t} ; \quad \delta+\phi=1
$$

The estimated equation is given in (9):

$$
\begin{aligned}
& \pi_{t}^{e}=\underset{(1.28)}{2.175}+0.607 \pi_{t-1}+0396 \pi_{t-1}^{e} \\
& T=34, R^{2}=0.89, \quad S E=3.27, D W=1.30
\end{aligned}
$$

These results are also consistent with the hypothesis of adaptive expectations and the hypothesis that $\delta+\phi=1$ is easily accepted. This further indicates that $\theta=0.6$ so that individuals base their inflation expectations today on their expectations last period plus $60 \%$ of last period's expectation error.

There is, though, an alternative to adaptive expectations that could explain the observed pattern of actual and expected inflation. Let us assume that inflation expectations are rational according to (1) but that individuals are uncertain about the policy of the government concerning inflation. Let us further assume that there can be two types of governments:

(10) Type A with the probability of $q_{t}$ and type B with the probability of $\left(1-q_{t}\right)$,

with government A always aiming for low inflation, $\pi_{t}^{L}$, but government B could target low or high inflation with a certain probability, i.e.:

(11) Government B chooses $\pi_{t}^{L}$ with the probability $p_{t}$ and $\pi_{t}^{H}$ with the probability $\left(1-p_{t}\right)$

Given these conditions and rational expectations we get (12) for inflation expectations:

$$
\pi_{t}^{e}=q_{t} \pi_{t}^{L}+\left(1-q_{t}\right) p_{t} \pi_{t}^{L}+\left(1-q_{t}\right)\left(1-p_{t}\right) \pi_{t}^{H}
$$

If we assume that the economy is in a period of disinflation we can for simplicity assume:

$$
\begin{aligned}
& \pi_{t}^{L}=0 \\
& \pi_{t}^{H}=\pi_{t-1}
\end{aligned}
$$

Equation (12) then becomes:

$$
\pi_{t}^{e}=\left(1-q_{t}\right)\left(1-p_{t}\right) \pi_{t-1}
$$

In (14) expectations can be rational even if they are only based on the past inflation rate. If we can estimate (14) using the formulation in (15):

$$
\pi_{t}^{e}=\alpha+\lambda \pi_{t-1}+u_{t} ; \quad \lambda=\left(1-q_{t}\right)\left(1-p_{t}\right)
$$

The result is:

$$
\begin{aligned}
& \pi_{t}^{e}=5.478+0.901 \pi_{t-1} \\
& \text { (1.41) (0.08) } \\
& T=34, R^{2}=0.83, S E=4.06, D W=0.62
\end{aligned}
$$


If we finally assume that individuals reassess their subjective probability about the nature of the government according to the following Bayes rule:

$$
q_{t+1}=\frac{\operatorname{Pr}\left(A \mid H_{t}=0\right) \operatorname{Pr}\left(\pi_{t}=0 \mid A\right)}{\operatorname{Pr}\left(\pi_{t}=0 \mid H_{t}=0\right)}=\frac{q_{t}}{q_{t}+\left(1-q_{t}\right) p_{t}}
$$

we can deduce:

$$
\lambda=1-\left\{q_{t}+\left(1-q_{t}\right) p_{t}\right\}=1-\operatorname{Pr}\left(\pi_{t}=0 \mid H_{t}=0\right)
$$

As $\lambda=0.9$, we get that $\operatorname{Pr}\left(\pi_{t}=0 \mid H_{t}=0\right)=0.1$. This low probability indicates that disinflation is far from credible. This low credibility provides an alternative explanation to adaptive expectations as to why expected inflation was, for an extended period, significantly higher than actual inflation. As they are observationally equivalent, it is very difficult to statistically distinguish between these two alternative hypotheses and their effects on variables like nominal interest rates and ex post real rates should be the same in both cases. From the standpoint of economic theory the credibility argument is, however, more elegant. 